\title{
Hydrogeochemical Study for sustainable development in Wadi El-Mathula, East Qift city, Eastern Desert, Egypt
}

\author{
Saad A. Mohallel
}

Hydrogeochemistry Department, Desert Research Center, El Matariya, Cairo, Egypt

Received: 15 Mar. 2020 / Accepted 20 April 2020 / Publication date: 30 April 2020

\begin{abstract}
Wadi El-Mathula is one of the promising basins in Upper Egypt. Rain fall, River Nile and return irrigation water represent the main recharging sources for groundwater aquifers in particular Quaternary water bearing. The hydrogeological data of the main aquifers, namely Quaternary and Nubian sandstone water bearing formations were discussed. The Quaternary aquifer occupying delta of Wadi El-Mathula, where it represented by 18 samples has a salinity ranges from fresh $(6 \%$ of samples) to brackish water (55\%) then saline water (39\%) showing an increase due east towards the new reclaimed and desert lands, where the values vary from $1320 \mathrm{mg} / 1$ to $10622 \mathrm{mg} / \mathrm{l}$ with mean value $5381 \mathrm{mg} / \mathrm{l}$. In the Nubian sandstone aquifer (represented by 6 samples) all the groundwater samples are brackish water where the salinity ranges from 1836 to $2682 \mathrm{mg} / \mathrm{l}$ with a mean value of $2072 \mathrm{mg} / \mathrm{l}$. Chloride - Sodium water type is considered the main water type where it characterized the majority $(67 \%)$ of the Quaternary groundwater samples and the majority of Nubian groundwater samples $(83 \%)$. Calcite and Dolomite dissolution beside the dissolution of halite are the main hydrochemical processes affecting groundwater quality. The chemical types and hypothetical salts as well as the ion ratios indicate meteoric origin for groundwater and dissolution of terrestrial salts. Hydrogeochemical model (PHREEQC 2.8) was used to calculate saturation indices of minerals to the Quaternary and the Nubian sandstone aquifers. The results indicated that the groundwater in the two aquifers is undersaturated with respect to Gypsum and Anhydrite indicating the capacity of groundwater for more mineral dissolution. All samples of the Nubian sandstone and the most samples of the Quaternary groundwater are supersaturated with reference to Calcite, Aragonite and Dolomite. The results of the environmental stable isotopes indicated that the groundwater in study area is discriminated into two distinctive groups. Group (I) belonging to the deep flowing well in Laqita area (Nubian aquifer) and group (II) of samples is enriched in their isotopic compositions (Quaternary aquifer). The investigated groundwater is not suitable for drinking purposes. Only $28 \%$ of the Quaternary groundwater samples are considered very satisfactory for all classes of livestock and poultry. On the other hand, all the groundwater samples of the Nubian sandstone aquifer are considered very satisfactory for all classes of livestock and poultry. About $5 \%$ of the Quaternary groundwater samples are Intermediate quality for irrigation. In addition the majority of the Nubian sandstone groundwater samples $(67 \%)$ are moderate water quality for irrigation and $17 \%$ of the groundwater samples in the same aquifer are Intermediate quality
\end{abstract}

Keywords: Hydrogeochemisty, Groundwater quality, Saturation indices, Environmental isotope, Wadi El Mathula, East Qift City.

\section{Introduction}

Groundwater is considered the essential water resource for land reclamation projects in desert areas and establishment of new settlements. Due to the huge population pressure in the narrow Nile Valley, it becomes more argument to search for new desert land areas for saving food and generating job opportunities. Selection of suitable sites for development is one of the most important steps involved in the development plans. Wadi El-Mathula basin that is locating in the Eastern Desert through Qift- El Qusseir road (Qena Governorate) is a promising area for reclamation projects and the future development plans for the following reasons; It is one of the most important areas which the Government wants to reclaim for saving job opportunities and increasing the income. It has a very wide flat areas and good soils that suitable for agricultural and industrial purposes. Presence of the most important aquifer in Egypt (Nubian Sandstone aquifer). The abundance of the required man powers for reclamation that area. Presence of different markets and factories for marketing the

Corresponding Author: Saad A. Mohallel, Hydrogeochemistry Department, Desert Research Center, El Matariya, Cairo, Egypt. E-mail: mohallel_drc@yahoo.com 
agricultural crops. Suitable climatic conditions for planting many crops. It has a paved network of roads especially Cairo -Aswan and Qift-El Quseir roads and it is not far away from the urban areas such as Qena, Qus, Qift, and El Quseir cities. Wadi El Mathula and its delta, (Figure 1), characterized by simple topography follows the regional northwest slopes towards the Nile. The average ground elevation varies from about $72 \mathrm{~m}$ above sea level in the western part (cultivated area) to about $126 \mathrm{~m}$ above sea level in the eastern part with a gentle slope to the northwest. It covers a region that includes both the floodplain and the desert fringes which extends to the downstream of the study area. During the last decade, a strip of the desert fringes has been reclaimed and irrigated completely with groundwater. In the near future, this area considers an important desert area for building new settlements (New Qena city, new Qift city, new industrial areas, etc.) and for new reclamation. These activities required a groundwater quality suitable for drinking, domestic and agricultural purposes. The sustainable use of water requires thorough understanding of the local geology, hydrogeology and hydrgeochemistry. Therefore the purpose of this paper is to study the hydrogeochemistry of the groundwater from the different aquifers and to obtain a comprehensive picture of the quality of the groundwater in the studied area.

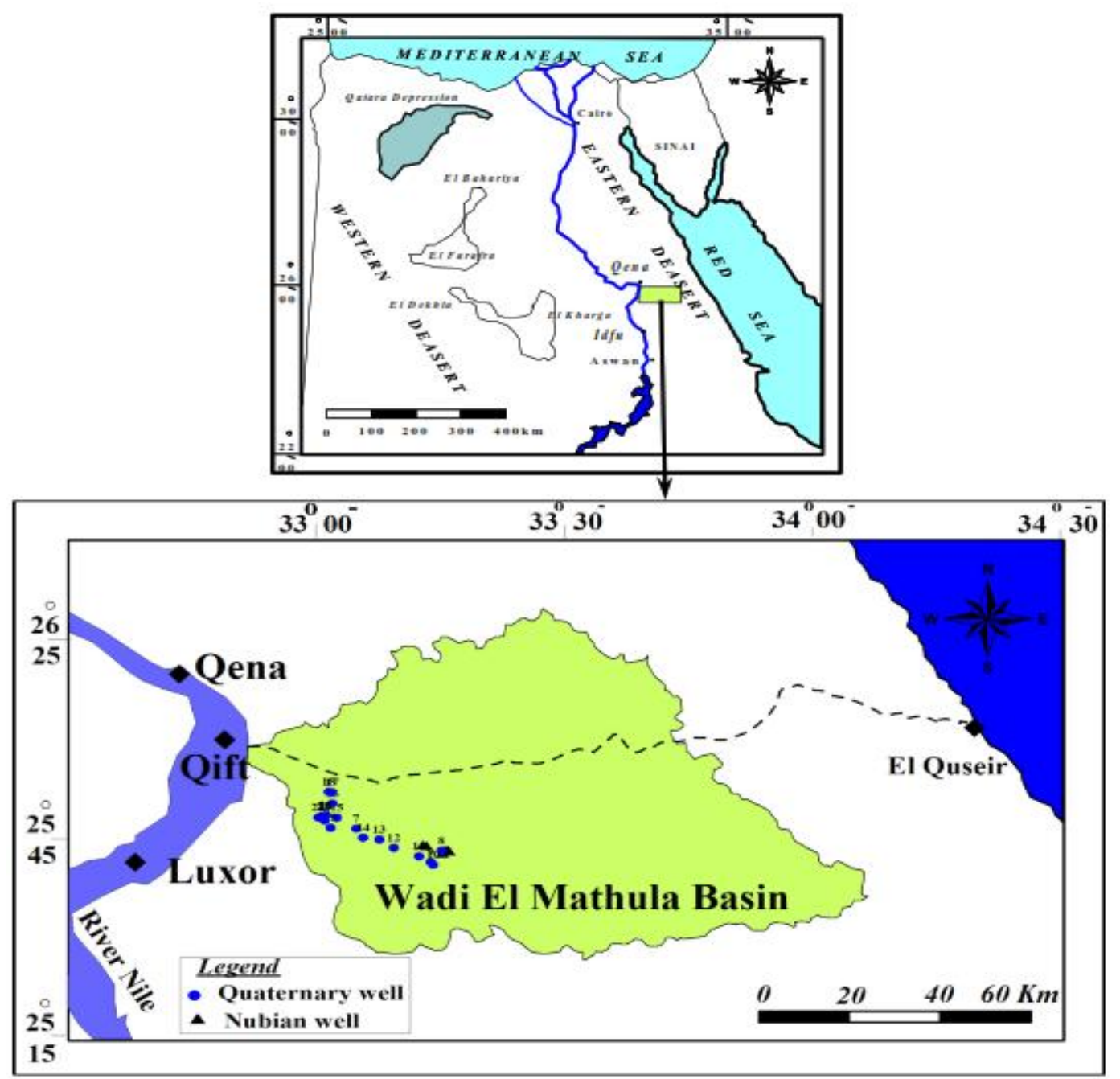

Fig. 1: Wells location map of the study area

The study area is characterized by long, hot, rainless summer and arid warm winter. The temperature varies from $27^{\circ} \mathrm{C}-47^{\circ} \mathrm{C}$ in the summer and from $7^{\circ} \mathrm{C}-28^{\circ} \mathrm{C}$ in the winter (Geriesh, 1998). Rainfall is rarely occurs and falls normally as thunderstorms with heavy showers during the transitional months (October-November and March-April). The maximum-recorded rainfall over 
Qena area in one day reaches up to $11.7 \mathrm{~mm} / \mathrm{d}$ in December, 1944. Generally, average annual rainfall does not exceed $4 \mathrm{~mm} /$ year.

\section{Geomorphology}

Geomorphologically, the study area had been included in the studies of El-Ghawaby, (1973) and El-Shamy, (1985). These studies revealed that the study area involves four main geomorphological units (Figures $2 \& 3$ ), they are from east to west; the upstream crystalline highlands, the middle Nubian sandstone plain, the downstream calcareous plateau and the hydrographic basins network dissecting the last three units and it drains westward to the Nile Valley. The following is a brief description of the geomorphological units:

\subsection{The Upstream Crystalline Highlands:}

According to El-Ghawaby, (1973), the crystalline highlands form a part of the rugged mountainous terrain related to the Arabio-Nubian shield. The topography shows a gradual increase in elevation eastwards where numerous high peaks and ridges exist. The main peaks in the area are G. Atalla 823m, G. El-Rubshi 996m, G. Meatiq 1112m, G. Muweilih 829m, G. Um-Khurs 912m, G. Um-Laseifa 1210m, G. Um-Bakra $901 \mathrm{~m}$ and G. El Eneigi $985 \mathrm{~m}$. These peaks form the natural water divide between hydrographic basins draining westward and those draining to the east. These crystalline highlands are composed mainly of basement rocks of different types.

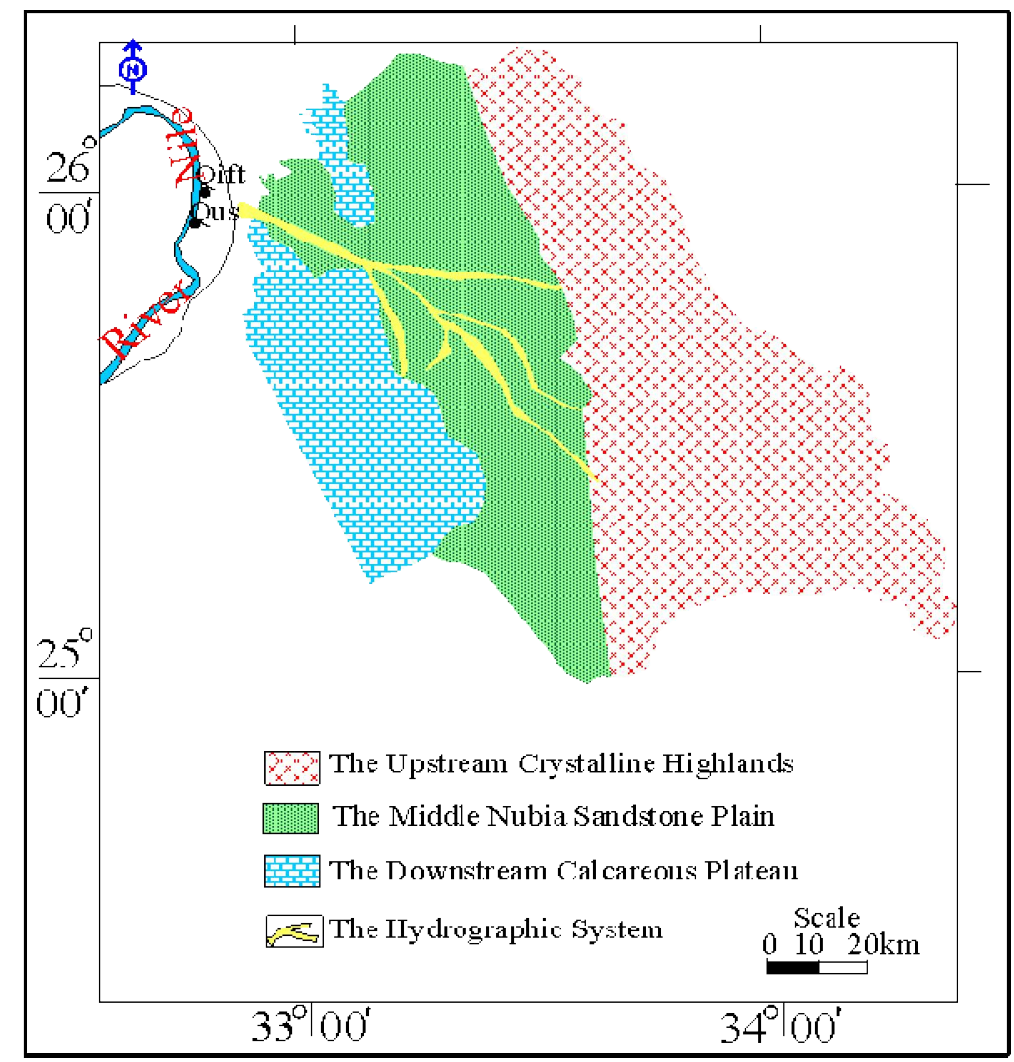

Fig. 2: Geomorphological Map of Wadi El-Mathula, (After El-Shamy, 1985). 


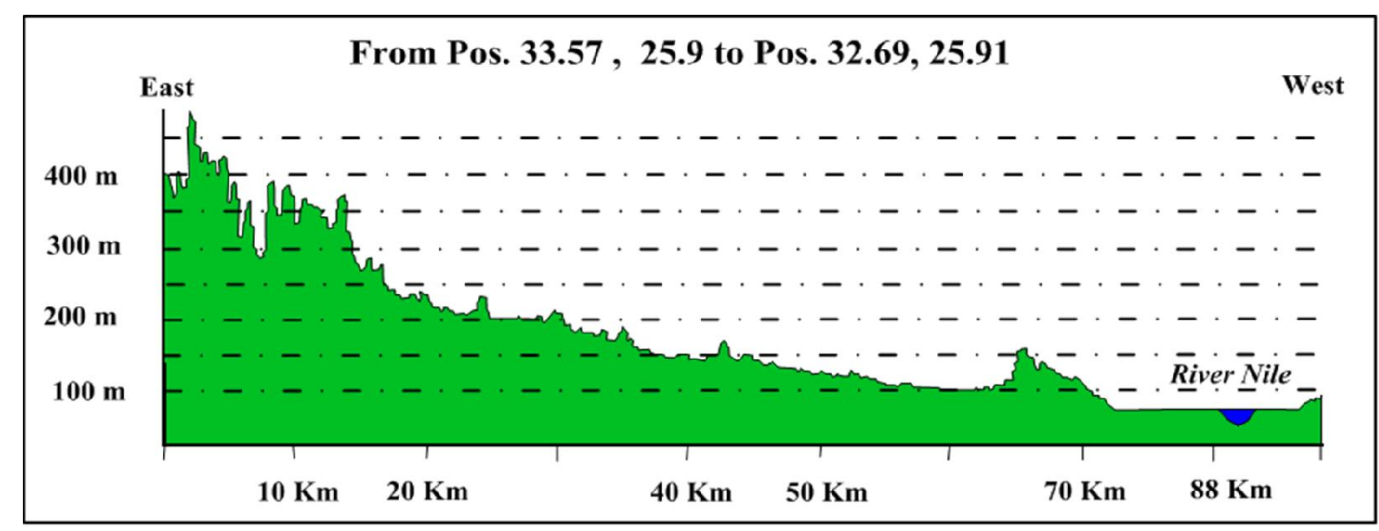

Fig. 3: Landscape sector of the study area

\subsection{The Middle Nubian Sandstone plain:}

This plainy terrain flanks the eastern crystalline highlands. The plain exhibits an undulated surface and is dissected by few wide drainage lines with several mesas and buttes of Nubian sandstone in the eastern part and/or of Cretaceous-Tertiary calcareous rocks in the downstream portion. The Nubian sandstone plain with its extensive Quaternary cover along the drainage channels and low areas forms a wide recharge area due to their good hydrologic properties.

\subsection{The Downstream Calcareous Plateau:}

El-Shamy, (1985) said that the downstream portion is covered by a calcareous plateau terminated from the west by an extended steep scarp overlooking the River Nile. The boundaries of the plateau have predominant structural lineaments that control the direction of the existing water courses in the downstream portion, e.g. W. El-Mathula attains a SE-NW direction. Moreover, the River Nile goes in parallel to the plateau. The calcareous plateau with its hills forms a conical watershed hilly area dissected by a radial drainage system of high density.

\subsection{The Hydrographic basins:}

El-Shamy, (1985) stated that the main basin in the study area is W. El-Mathula, which dissects the eastern mountainous watershed and the foreland Nubian sandstone. Many tributaries are forming the hydrographic basin of Wadi El-Mathula, such as, W. El-Mashash, W. Atwany, W. Al-Qarn, W. Uqadiyah, W. Manih, W. Abu-Wasil, W. Abu-Tanudbah, W. Atallah, W. Al-Qash and W. Zeidon, (Figure 4). The upstream first and second order tributaries are mostly short and narrow with U-shaped cross sections and are mostly occupied by large boulders of disintegrated products. Most of the higher order branches are wider with V-shaped cross sections where some of them are covered with Wadi filling deposits. In the Nubian sandstone country, the hydrographic system is represented by few very wide water courses with several hills of Nubian sandstone. In general, the number and length of channels which dissect the Nubian sandstone surface are smaller than those dissecting both the eastern and western highlands. The dominant drainage pattern in the upstream basement highlands is dendritic, while in the Nubian sandstone country it is parallel.

\section{Geological Setting}

Many efforts had been devoted to delineate the geological setting of the Eastern Desert including the study area. These aspects were attempted by Youssef, (1957), Said, (1962 and 1981), Amer, (1970), Ghanem et al., (1970), Abdel Razik et al., (1972), El-Ghawaby, (1973), Sabet et al., (1985), Soliman et al., (1986), Issawi et al., (1987), El-Hussaini et al., (1990), El-Fakharany and Dahab (1997).

The study area is built up mainly of Quaternary sediments forming the delta of wadi El Mathula. Wadi El Mathula and its sub-basins cut through the basement rocks at the eastern part, and sedimentary rocks at the western part. The sedimentary rocks are related to Upper Cretaceous-Lower Eocene age which is unconformably overlain by Pliocene and Quaternary deposits and underlain by 
Precambrian basement rocks (Abu Al-Izz 1971, El-Rakaiby 1990, Farrage et al., 1996, El-Fakharany 1998, Abdel Moneim, 2004).

Upper Cretaceous-Lower Eocene section is subdivided into Nubian Sandstoneat the base followed by Qusier shale, Duwi Formation, Dakhla shale, and Thebes Formation. The Quaternary deposits classified into Khuzam shale at the base followed by Durri limestone, Hagaza Formation, and Issawia Formation. The recent deposits comprise unconsolidated sediments represented by Nile floodplain, wadi deposits, fanglomerates, and sand dunes which extend to the downstream of Wadi El-Mathula basin.

The Precambrian basement rocks are primarily exposed due east and include serpentinite, gabbroic to granite, meta-volcanic intrusive, and various volcanic and geosynclinals meta-sediments.

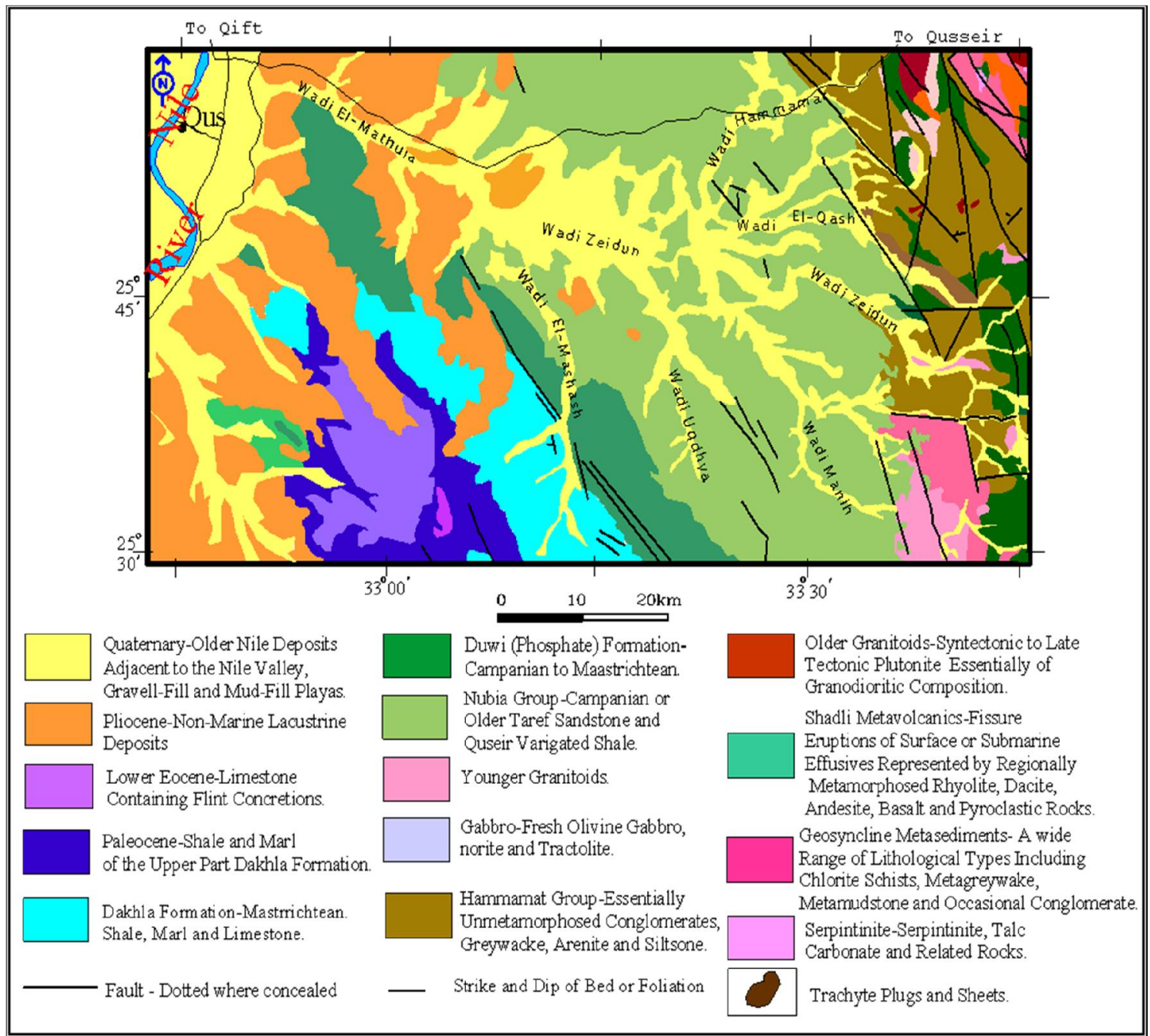

Fig. 4: Geological Map of Wadi El-Mathula, (After the Egyptian Geological Survey and Mining Authority, 1978)

\section{Hydrogeology}

Many studies have been done and focused on the hydrogeological setting of the study area (Senosy 1988, Abdalla 1995, Farrage et al., 1996, Ibrahim et al., 1997, Abu El-Ela et al., 1997, El Tahlawi et al., 2008, Tawfik, 2011 and Abd-Allatief et al., 2012). They concluded that:

\subsection{The Quaternary aquifer}

It is composed mainly of alluvial deposits which is consists of gravel, sand, silt and clay. This water-bearing formation exists in the Delta of Wadi El Mathula and in the main channel and not 
detected at the extreme eastern part of the investigated area. Its thickness ranges from $2.8 \mathrm{~m}$ to $180 \mathrm{~m}$. Based on the fact of increasing the thickness of this aquifer towards the northwestern direction, it can be concluded that the groundwater potentiality of this aquifer is increasing towards the northwestern direction through the main channel of Wadi El-Mathula. This aquifer exists under unconfined conditions and the extracted water is brackish and saline type and it is suitable for agricultural purposes. The depth to water of the Quaternary aquifer varies from $5 \mathrm{~m}$ in the delta of Wadi El Mathula to $54 \mathrm{~m}$ in the North of Qift City part of the study area, (Table 1). This aquifer is recharged mainly from the precipitation, return flow after irrigation water, (Mohammed, 2016) and from the Nubian sandstone aquifer through the present fault plains.

\subsection{The Nubian Sandstone aquifer}

It is composed mainly of sand with intercalations of shale (Nubian Sandstone). The thickness of this aquifer is less than $22.3 \mathrm{~m}$ at the eastern part and increases westwards to more than $700 \mathrm{~m}$ at the central part of the study area. It is noticed that the depth to the surface of this aquifer is less than $30 \mathrm{~m}$ at the eastern part of the main channel and it increases westwards to more than $150 \mathrm{~m}$ at the central part of the study area. This water bearing formation represents the main aquifer (Cretaceous aquifer) in Wadi El-Mathula. The groundwater potentiality of this aquifer is increasing towards the northwest direction. This aquifer is underlain a clay layer (impervious layer) and it overlays basement rocks which mean that this aquifer exists under confined conditions. From the geoelectrical cross sections, it is obvious that there is a lateral connection between this aquifer and the first aquifer through the inferred fault plains. The Nubian aquifer is considered deep aquifer. The water in the drilled wells in the study area is flowing with a head ranges from 1.34 to $9.30 \mathrm{~m}$ above the ground surface. The natural discharge change of the wells are ranging from 168 to $1500 \mathrm{~m}^{3} /$ day, (Regwa, 1983).

\subsection{The Fractured Basement aquifer}

It is detected at the far eastern part of the study area; its thickness varies from $15 \mathrm{~m}$ to $25.4 \mathrm{~m}$. The potentiality of this aquifer is limited and there are no drilled wells extract the water from it, (Tawfik, 2011).

\section{Sampling and analysis}

A total of 27 water samples were collected from the investigated area (18 hand dug and drilled wells, 6 flowing wells, 2 surface water samples and a Rain water sample) in November 2019. The wells are mostly used for agricultural irrigation and drinking. The depth of the wells varies. Location of sampling points is illustrated in Figure 1. Samples, for measurement of heavy metals and major ions, were collected in a separate polyethylene containers; to prevent the deposition of heavy metals, approximately $2 \mathrm{ml}$ of nitric acid with a concentration of $65 \%$ was added to the samples. Parameters such as acidity $(\mathrm{pH})$ and electrical conductivity $(\mathrm{EC})$ were measured in situ. The concentrations of calcium $(\mathrm{Ca})$, magnesium $(\mathrm{Mg})$, chloride $(\mathrm{Cl})$, Carbonate $\left(\mathrm{CO}_{3}\right)$ and bicarbonates $\left(\mathrm{HCO}_{3}\right)$ were measured volumetrically, sodium $(\mathrm{Na})$ and potassium $(\mathrm{K})$ by flame photometry, sulfate $\left(\mathrm{SO}_{4}\right)$ by spectrophotometer at the Central lap of Desert Research Center. The analysis of heavy metals such as Silver (Ag),Aluminum (Al), Boron (B), Barium (Ba), Cadmium (Cd), Cobalt (Co), Iron (Fe), Lithium $(\mathrm{Li})$, Manganese $(\mathrm{Mn})$, Lead $(\mathrm{Pb})$, Nickle $(\mathrm{Ni})$, Chromium $(\mathrm{Cr})$, Copper $(\mathrm{Cu})$, Strontium $(\mathrm{Sr})$, Vanadium (V), Zinc (Zn) and Molybdenum (Mo) are detected by I.C.P Spectrophotometer Thermo Jarrel Ash model POEMS 3, using 1000 ppm (Merck) Stock solution for standard preparation in the Central Lap of Desert Research Center, Cairo, Egypt.

Stable isotopes of oxygen $\left({ }^{18} \mathrm{O}\right.$ and $\left.{ }^{16} \mathrm{O}\right)$ and hydrogen $\left({ }^{2} \mathrm{H}\right.$ and $\left.{ }^{1} \mathrm{H}\right)$ were conducted in the Stable Isotope Geochemistry Lab of the Department of Geosciences at Western Michigan University. Oxygen and hydrogen isotope ratios were measured using Los Gatos Research (LGR) Off-Axis Integrated Cavity Output spectroscopy (off-Axis ICOS) technology. Four routine analyses, calibrated laboratory working standards that have been calibrated with respect to VSMOW and SLAP have been used. The isotopic composition of oxygen and hydrogen are reported in terms of delta $(\delta)$ notation in permil (\%, parts per thousand) and defined as follows:

$$
\delta_{\text {sample }} \%=\left(\left(\mathbf{R}_{\text {sample }}-\mathbf{R}_{\text {standard }}\right) /\left(\mathbf{R}_{\text {standard }}\right)\right) \times \mathbf{1 0 0 0}
$$


Int. J. Environ., 9(2):60 -82, 2020

Table 1: Depth to water of the observation wells in the study area, (2019).

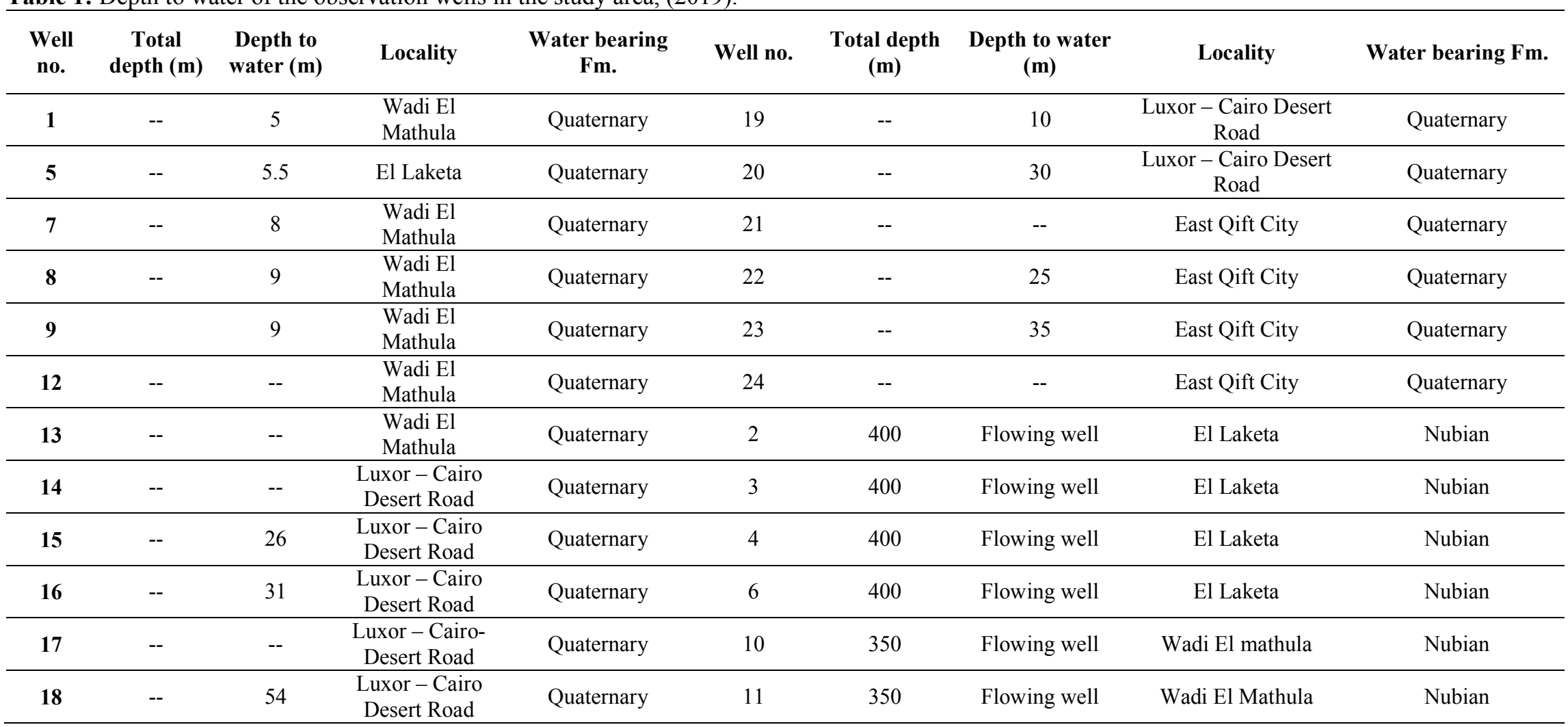


Where $\mathrm{R}_{\text {sample }}$ is $\left({ }^{2} \mathrm{H} /{ }^{1} \mathrm{H}\right)$ or $\left({ }^{18} \mathrm{O} /{ }^{16} \mathrm{O}\right)$ in the sample and $\mathrm{R}_{\text {standard }}$ is the corresponding ratio for the standard. The $\delta$ values are reported with respect to Vienna Standard Mean Ocean Water (VSMOW). Repeated analyses of internal standards provide an analytical precision of $0.1 \%$ for oxygen and $0.5 \%$ for hydrogen respectively. Craig (1961) reported that the hydrogen and oxygen isotope ratios of precipitation that have not undergone evaporation are linearly correlated by the relationship:

$$
\delta^{2} \mathrm{H}=8 \delta^{18} \mathrm{O}+10
$$

This is called the Global Meteoric Water Line (GMWL) and defines the loci of fresh water that was produced by condensation from a vapor under isotopic equilibrium conditions.

\section{Results and Discussion}

\section{Groundwater Chemistry}

Twenty-Four groundwater samples (6 groundwater samples represent the Nubian sandstone aquifer, 18 groundwater samples represent the Quaternary aquifer), besides two surface water samples were collected in November 2019 from the study area, the differentiation between the Quaternary aquifer samples and the Nubian sandstone aquifer samples is based on the depth of sampling and description of the lithologic logs of the wells in relation to the existing geologic conditions in addition to the review of the available literature. The hydrochemical analysis for major elements and some heavy metals were performed in the central lab, Desert Research Center (DRC), Cairo, Egypt, according to the methods adopted by the United States Geological Survey (Rainwater and Thatcher, 1960), methods of determination for inorganic substances in water and fluvial sediments (Fishman and Friedman, 1985 and American Society for Testing and Materials ASTM, 2002), (Table 2).The descriptive statistics of the chemical parameters (minimum, maximum, mean, median, and standard deviation) for the collected samples were calculated, (Tables $3 \& 4$ ).

According to the hydrochemical analyses data, the following could be deduced:

The Quaternary groundwater temperature ranges from $22.5^{\circ} \mathrm{C}$ (No. 7) in Qift area to $30.8^{\circ} \mathrm{C}$ (No. 18) in Qift - El Quseir Desert Road, where the aquifer is mainly subjected to the atmospheric pressure. In Nubian sandstone aquifer, the groundwater temperature ranges from $25.8{ }^{\circ} \mathrm{C}$, (No. 2) to $35.5^{\circ} \mathrm{C}$ (No. 3) in Laketa area which indicates that the groundwater is subjected to high pressure and isolated from the atmospheric pressure. $\mathrm{pH}$ values of the examined groundwater samples range from 6.75 (No. 16) in Qift area to 7.5 (No. 2) in Laketa area, reflecting a neutral groundwater.

\section{1. Electrical Conductivity (EC):}

EC values in the Quaternary groundwater samples range from $2346 \mu \mathrm{S} / \mathrm{cm}$ at well 21 located in the cultivated land to $19270 \mu \mathrm{S} / \mathrm{cm}$ at well 14 (Menifery Company for reclaimed land) is located in the Desert (reclaimed) land. The (EC) values in the Nubian sandstone groundwater samples ranges between $3540 \mu \mathrm{S} / \mathrm{cm}$ at well 6 located in Laketa area to $3750 \mu \mathrm{S} / \mathrm{cm}$ at well 10 is located in Laketa area. The (EC) values showed a decrease in the samples of the cultivated lands due to the infiltration from the surface water through canals and irrigation water while the values increase towards the Desert and reclaimed lands.

\section{2. Total dissolved solids (TDS):}

Quaternary groundwater salinity indicate that $6 \%$ of the total samples are fresh (No. 21) and the majority of the Quaternary groundwater samples (55\%) are brackish (Nos. 17, 18, 19, 23, 22, $24,7,8,5 \& 15$ ), while $39 \%$ are saline (Nos. $20,9,13,12,16,14 \& 1$ ). Where the salinity values range from $1320.5 \mathrm{mg} / 1$ to $10622.07 \mathrm{mg} / 1$ with mean value $5381.4 \mathrm{mg} / \mathrm{l}$. TDS values increase to the east direction of the area towards the reclaimed or Desert land, this is due to the highest percentages of agricultural land uses, increasing of groundwater evaporation, the absence of recharge from the irrigation canals as in the cultivated land and the dissolution of rocks by the amount of rainfall. In the Nubian sandstone aquifer, all the groundwater samples are brackish water where the salinity ranges from 1836.6 to $2682.4 \mathrm{mg} / \mathrm{l}$.

Since the EC and TDS are measurements of the total salt content, they must be directly proportional. The correlation between these two parameters for the analyzed samples in this study was plotted in figure (5), which showed a linear correlation with a mathematical approximation of (TDS $\mathrm{mg} / \mathrm{L}=0.65 \mathrm{EC} \mu \mathrm{S} / \mathrm{cm})$. The value is usually between 0.5 and 0.75 (Hem, 1985). 
Int. J. Environ., 9(2):60 -82, 2020

Table 2: Hydrochemical analyses data of the investigated groundwater samples in $\mathrm{mg} / \mathrm{l}$

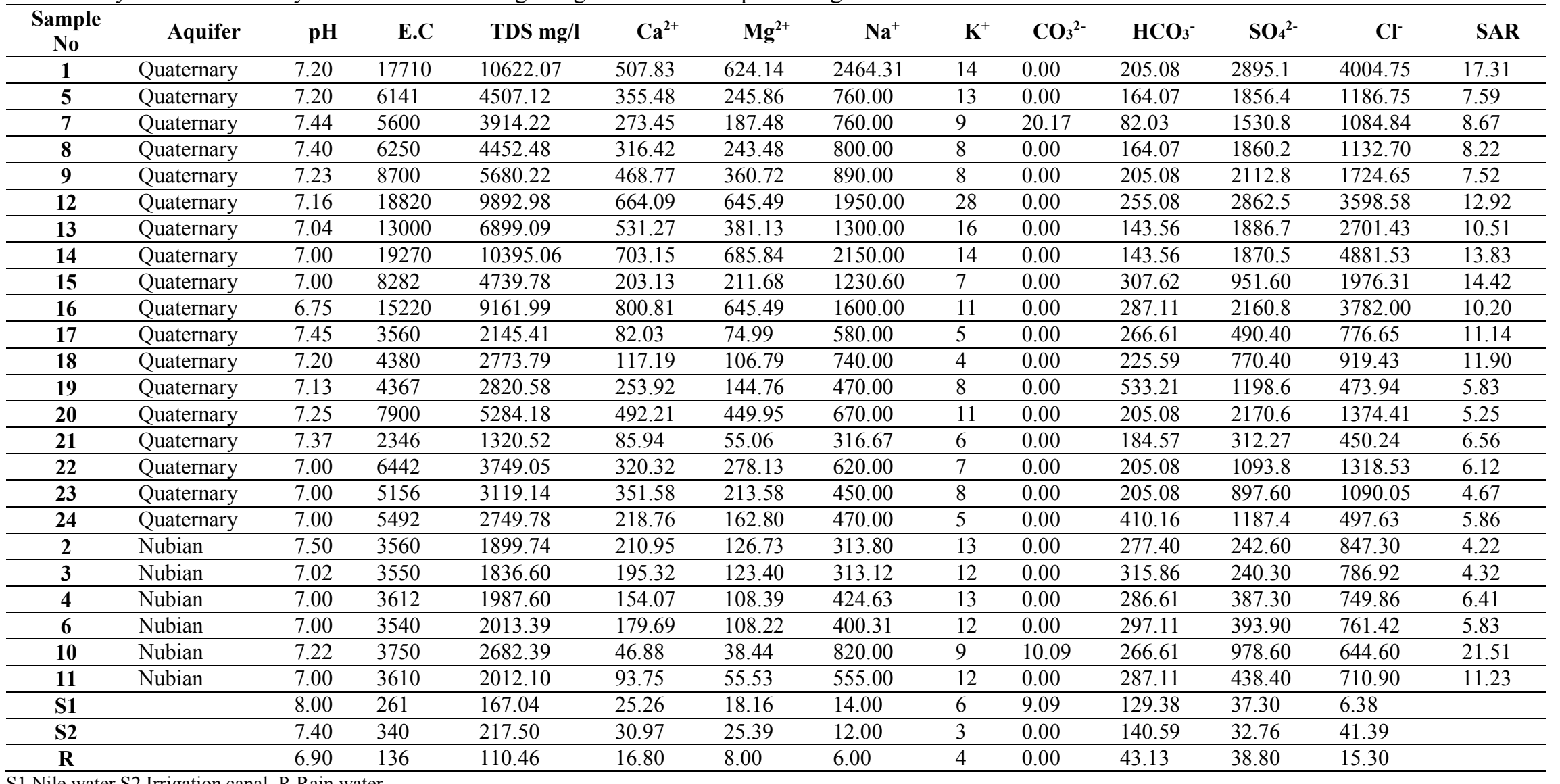

S1 Nile water S2 Irrigation canal R Rain water 
Int. J. Environ., 9(2):60 -82, 2020

Table 2: Cont.

\begin{tabular}{|c|c|c|c|c|c|c|c|c|c|c|c|c|c|}
\hline S.N & Aquifer & Ag & Al & B & $\mathbf{B a}$ & $\mathrm{Cr}$ & $\mathrm{Cu}$ & $\mathbf{F e}$ & $\mathbf{L i}$ & Mn & $\mathbf{N i}$ & $\mathbf{P b}$ & $\mathrm{Sr}$ \\
\hline 1 & Quaternary & 0 & 0.125 & 0.227 & 0.009 & 0.039 & 0.015 & 0.051 & 0.098 & 0 & 0.0014 & 0 & 8.308 \\
\hline 5 & Quaternary & 0 & .2379 & 0 & .0211 & .0458 & 0 & .0971 & .0474 & .0617 & 0 & .0837 & 6.956 \\
\hline 7 & Quaternary & .0163 & .0670 & 0 & .0199 & .0786 & 0 & .4112 & .0465 & .0356 & 0 & 0 & 6.516 \\
\hline 8 & Quaternary & .0370 & .0539 & 0 & .0173 & .0031 & 0 & 0 & .0581 & .0101 & 0 & 0 & 8.995 \\
\hline 9 & Quaternary & .0301 & .1039 & 0 & .0139 & 0 & .0105 & .3148 & .0687 & 0 & 0 & 0 & 12.07 \\
\hline 12 & Quaternary & .0638 & .2534 & 0 & .0237 & 0 & 0 & .0295 & .1100 & .1126 & 0 & 0 & 16.15 \\
\hline 13 & Quaternary & .0144 & .2011 & .1477 & .0028 & .0173 & 0 & .8725 & .1020 & .0113 & .0389 & 0 & 9.332 \\
\hline 14 & Quaternary & .0187 & .1904 & .4379 & .0144 & .0541 & 0 & .5132 & .1901 & 0 & .0356 & 0 & 16.51 \\
\hline 15 & Quaternary & 0 & .0552 & 0 & .0145 & .0475 & 0 & .8301 & .0190 & .1396 & .0356 & 0 & 4.440 \\
\hline 16 & Quaternary & .0012 & 0 & .6656 & .0268 & .0592 & .0038 & .3923 & .0670 & .0083 & 0 & 0 & 16.53 \\
\hline 17 & Quaternary & .0189 & .2028 & 0 & .0202 & .0098 & 0 & .3084 & .0214 & .0098 & 0 & .1628 & 1.797 \\
\hline 18 & Quaternary & 0 & .1516 & 0 & .0291 & .1325 & 0 & .1120 & .0204 & 0 & 0 & 0 & 2.258 \\
\hline 19 & Quaternary & 0 & .0754 & 0 & .0047 & .0567 & 0 & .1044 & .0422 & .0165 & 0 & 0 & 4.147 \\
\hline 20 & Quaternary & 0 & .5025 & 1.492 & .0791 & .0859 & 0 & .3389 & .0497 & .0298 & .1032 & 0 & 10.32 \\
\hline 21 & Quaternary & 0 & .1469 & 0 & .0209 & .0014 & .0082 & .1191 & .0187 & .0111 & .0682 & 0 & 1.504 \\
\hline 22 & Quaternary & .0313 & .1928 & .1186 & .0199 & .0273 & .0068 & .6272 & .0357 & .0169 & .0523 & 0 & 6.884 \\
\hline 23 & Quaternary & .0088 & .3679 & 0 & .0730 & .0970 & 0 & .0724 & .0281 & 0 & 0 & 0 & 4.564 \\
\hline 24 & Quaternary & 0 & .0849 & 0 & .0151 & .0325 & 0 & 0 & .0136 & .1314 & 0 & 0 & 2.670 \\
\hline 3 & Nubian & .0264 & .0944 & 0 & .0143 & .0006 & 0 & 1.556 & .0285 & .0926 & .0039 & .0962 & 5.296 \\
\hline 4 & Nubian & 0 & 0 & 0 & .0150 & .0644 & 0 & 1.918 & .0309 & .1338 & 0 & 0 & 4.745 \\
\hline 6 & Nubian & .0726 & .0813 & 0 & .0163 & .0399 & 0 & 3.465 & .0222 & .1577 & .0273 & 0 & 5.374 \\
\hline 10 & Nubian & .0358 & .0766 & 0 & .0136 & 0 & 0 & 0 & .0187 & .0091 & .0790 & 0 & .8237 \\
\hline 11 & Nubian & .0139 & 0 & 0 & .0102 & 0 & 0 & .3905 & .0221 & .2235 & .0757 & 0 & 1.868 \\
\hline S1 & & - & - & - & - & - & - & - & - & - & - & - & - \\
\hline S2 & & .0170 & .2088 & 0 & .0246 & .0207 & 0 & .3048 & .0016 & .0706 & 0 & 0 & .1951 \\
\hline $\mathbf{R}$ & & - & - & - & - & - & - & - & - & - & - & - & - \\
\hline
\end{tabular}

S1 Nile water S2 Irrigation canal R Rain water 
Int. J. Environ., 9(2):60 -82, 2020

Table 3: Descriptive statistics of the investigated Quaternary groundwater samples.

\begin{tabular}{|c|c|c|c|c|c|c|}
\hline Items & Minimum & Maximum & Standard Deviation & Variance & Median & Mean \\
\hline pH & 6.75 & 7.45 & 0.19 & 0.03 & 7.18 & 7.16 \\
\hline Temp. & 22.50 & 30.80 & 2.63 & 6.91 & 26.70 & 26.92 \\
\hline EC & 2346.00 & 19270.00 & 5483.91 & 30073245.87 & 6346.00 & 8813.11 \\
\hline TDS & 1320.52 & 10622.07 & 2955.39 & 8734313.75 & 4479.80 & 5234.86 \\
\hline $\mathrm{Ca}$ & 82.03 & 800.81 & 211.34 & 44664.06 & 335.95 & 374.80 \\
\hline Mg & 55.06 & 685.84 & 209.37 & 43837.29 & 244.67 & 317.63 \\
\hline $\mathbf{N a}$ & 316.67 & 2464.31 & 635.49 & 403852.77 & 760.00 & 1012.31 \\
\hline $\mathbf{K}$ & 4.00 & 28.00 & 5.63 & 31.75 & 8.00 & 10.11 \\
\hline $\mathrm{CO}_{3}$ & 0.00 & 20.17 & 4.75 & 22.61 & 0.00 & 1.12 \\
\hline $\mathrm{HCO}_{3}$ & 82.03 & 533.21 & 104.66 & 10954.18 & 205.08 & 232.93 \\
\hline $\mathrm{SO}_{4}$ & 312.27 & 2895.12 & 748.35 & 560023.11 & 1693.60 & 1561.58 \\
\hline $\mathrm{Cl}$ & 450.24 & 4881.53 & 1365.54 & 1864699.43 & 1252.64 & 1831.91 \\
\hline
\end{tabular}

Table 4: Descriptive statistics of the investigated Nubian groundwater samples.

\begin{tabular}{|c|c|c|c|c|c|c|}
\hline Items & Minimum & Maximum & Standard Deviation & Variance & Median & Mean \\
\hline pH & 7.00 & 7.50 & 0.20 & 0.04 & 7.01 & 7.12 \\
\hline Temp. & 25.80 & 35.30 & 3.84 & 14.71 & 31.75 & 31.32 \\
\hline EC & 3540.00 & 3750.00 & 77.93 & 6072.67 & 3585.00 & 3603.67 \\
\hline TDS & 1836.60 & 2682.39 & 307.18 & 94360.12 & 1999.85 & 2071.97 \\
\hline Ca & 46.88 & 210.95 & 63.88 & 4080.46 & 166.88 & 146.78 \\
\hline Mg & 38.44 & 126.73 & 37.17 & 1381.81 & 108.30 & 93.45 \\
\hline $\mathrm{Na}$ & 313.12 & 820.00 & 192.69 & 37128.41 & 412.47 & 471.14 \\
\hline $\mathbf{K}$ & 9.00 & 13.00 & 1.47 & 2.17 & 12.00 & 11.83 \\
\hline $\mathrm{CO}_{3}$ & 0.00 & 10.09 & 4.12 & 16.95 & 0.00 & 1.68 \\
\hline $\mathrm{HCO}_{3}$ & 266.61 & 315.86 & 16.92 & 286.14 & 286.86 & 288.45 \\
\hline $\mathrm{SO}_{4}$ & 240.30 & 978.60 & 273.34 & 74712.07 & 390.60 & 446.85 \\
\hline $\mathrm{Cl}$ & 644.60 & 847.30 & 68.70 & 4719.68 & 755.64 & 750.17 \\
\hline
\end{tabular}




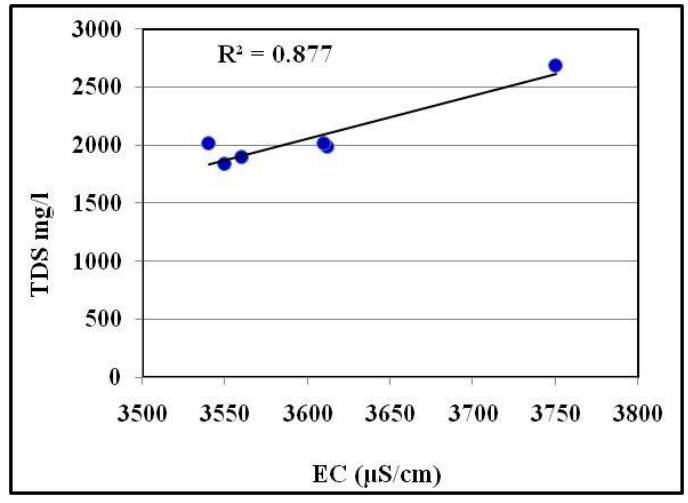

(a)

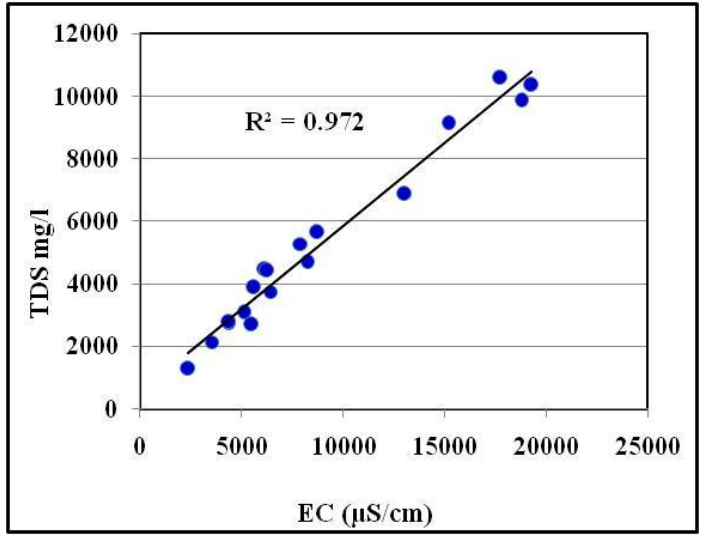

(b)

Fig. 5: The correlation between EC $(\mu \mathrm{S} / \mathrm{cm})$ and TDS $(\mathrm{mg} / \mathrm{l})$ in the Nubian aquifer (a) and Quaternary aquifer (b).

\subsection{Total Hardness}

According to the chemical analysis of the groundwater samples, it was noticed that the mean values of total, permanent and temporary hardness of the Quaternary groundwater samples attain 441.26, 289.85 and $151.41 \mathrm{mg} / \mathrm{l}$ as $\mathrm{CaCO}_{3}$ in the fresh Quaternary groundwater respectively and $1391.98,1178.32$ and $213.66 \mathrm{mg} / 1$ in the brackish Quaternary groundwater respectively and 3717.32, 3548.04 and $169.29 \mathrm{mg} / \mathrm{l}$ in the saline Quaternary groundwater respectively. These data indicate an increase in total and permanent hardness with the increase of water salinity except the relation with temporary hardness, (Figure 6). This is mainly attributed to the effect of leaching and dissolution of soluble salts which lead to the increase of hardness with particular importance to the effect of $\mathrm{NaCl}$ on increasing solubility of $\mathrm{Ca}^{2+}$ and $\mathrm{Mg}^{2+}$ in water (Freeze and Cherry, 1979), taking into consideration the contribution of the $\mathrm{CO}_{2}$ and longer residence time as well as the influence of salty water and cation exchange processes. In the Nubian sandstone aquifer it was noticed that the mean values of total, permanent and temporary hardness of the groundwater samples attain 751.23, 511.81 and $239.49 \mathrm{mg} / \mathrm{l}$ as $\mathrm{CaCO}_{3}$ respectively.

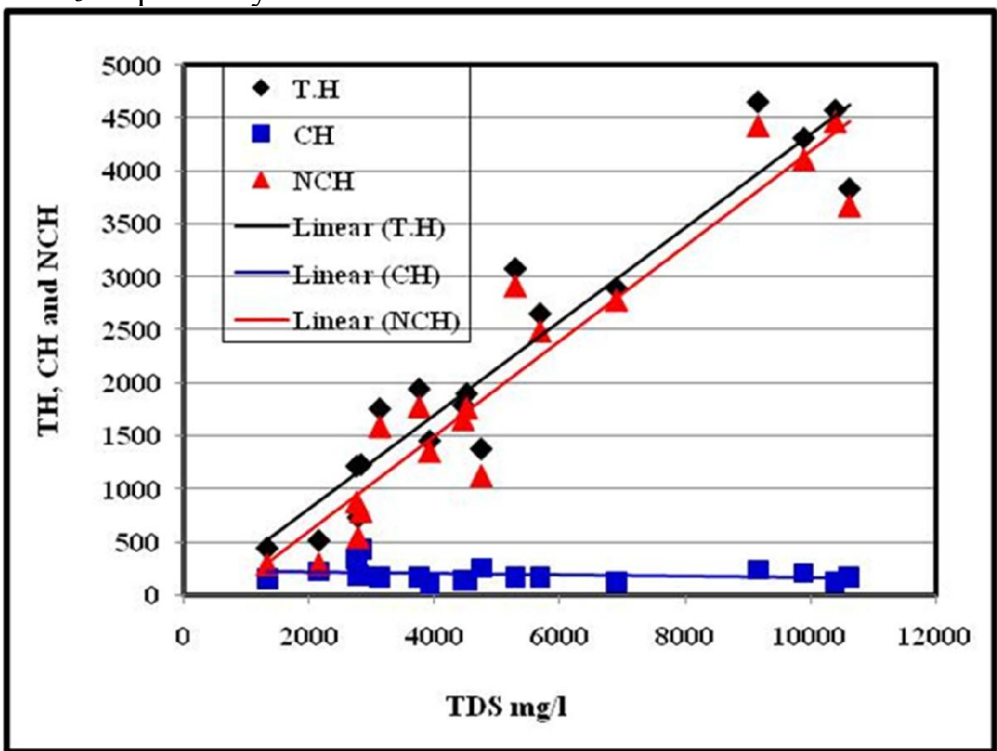

Fig. 6: Relationship between water salinity and hardness in the Quaternary groundwater at the study area.

\section{Chemical water types}

The distribution of water chemical types in the study aquifer is classified according to the dominant anions and cations into: 


\subsection{Chloride - Sodium}

Characterizing the majority (67\%) of the Quaternary groundwater samples and the majority of Nubian groundwater samples $(83 \%)$ which represents the most advanced stage of groundwater metasomatism reflecting the leaching and dissolution of terrestrial salts.

\subsection{Sulfate - Sodium}

This water type (intermediate stage) rich in sulfatecharacterizing $28 \%$ of the Quaternary groundwater samples and the rest samples of Nubian aquifer (17\%). This type of water reflects the leaching and dissolution of terrestrial salts.

\subsection{Sulfate - Calcium}

Dominating only5\% of the Quaternary groundwater samples of the study area.

\section{Hydrochemical processes that control water quality}

To clarify the Chemical facies, groundwater classification, and hydrochemical processes in the study area, data were analyzed using piper (1944) diagram. The type of water often indicates the origin of its composition in nature and the phase of its salinity development in the different geological areas of the aquifers. According to piper (1944), the majority of the Quaternary groundwater samples $(67 \%)$ and about $50 \%$ of the Nubian sandstone groundwater samples are located in the first class (Figure 7) which belong to the secondary salinity water type where strong acids $\left(\mathrm{Cl}^{-}, \mathrm{SO}_{4}^{-}\right)$predominance over weak acids $\left(\mathrm{HCO}_{3}{ }^{-}, \mathrm{CO}_{3}{ }^{2-}\right)$ and earth alkaline elements $\left(\mathrm{Ca}^{2+}, \mathrm{Mg}^{2+}\right)$ predominance over alkali element $\left(\mathrm{Na}^{+}, \mathrm{K}^{+}\right)$, with hydrochemical facies $\left(\mathrm{Ca}^{2+}-\mathrm{Mg}^{2+}-\mathrm{Cl}^{-}-\mathrm{SO}_{4}^{2-}\right),(12$ samples represent the Quaternary aquifer and 3 samples represent the Nubian sandstone aquifer). The rest groundwater samples of the Quaternary aquifer (33\%) and $50 \%$ of the Nubian sandstone samples are located in the third class, which belong to primary salinity water type where alkali elements $\left(\mathrm{Na}^{+}, \mathrm{K}^{+}\right)$predominance over earth alkaline elements $\left(\mathrm{Ca}^{2+}, \mathrm{Mg}^{2+}\right)$ and strong acids $\left(\mathrm{Cl}^{-}, \mathrm{SO}_{4}{ }^{2-}\right)$ predominance over weak acids $\left(\mathrm{HCO}_{3}{ }^{-}, \mathrm{CO}_{3}{ }^{2-}\right)$ with the hydrochemical facies $\left(\mathrm{Na}^{+}-\mathrm{K}^{+}-\mathrm{Cl}^{-}-\mathrm{SO}_{4}{ }^{2-}\right)$.

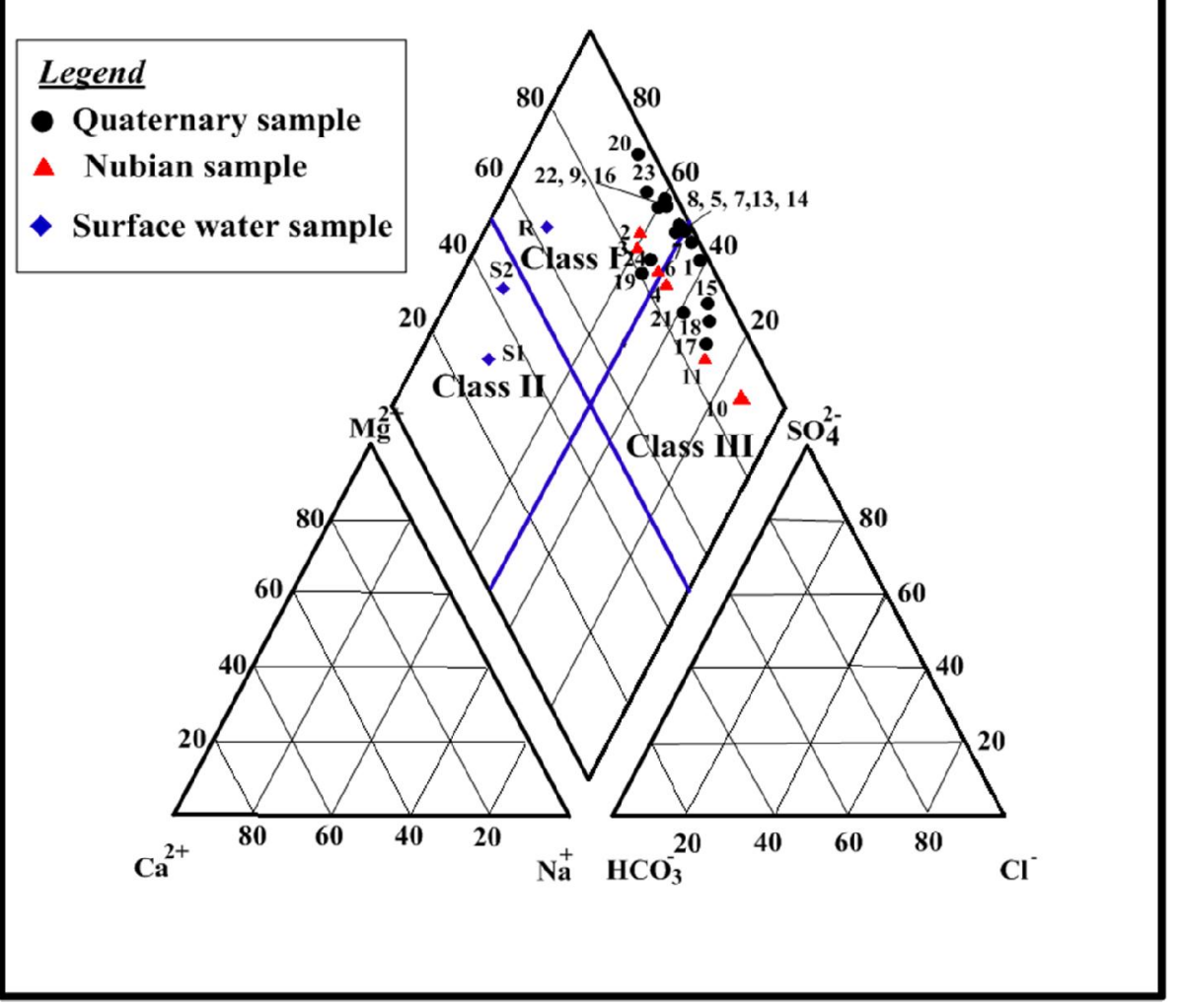

Fig. 7: Piper trilinear diagram for groundwater samples of the Quaternary and Nubian aquifer in the study area. 


\section{Ion Ratios}

\section{1. $\left(\mathrm{rNa}^{+} / \mathrm{rCl}^{-}\right)$}

The molar ratio $\mathrm{Na}^{+} / \mathrm{Cl}^{-}$is a well-known criterion to determine the source of salinity in groundwater system. In this study, the estimated ratios of $\mathrm{Na}^{+} / \mathrm{Cl}^{-}$for the majority of the Quaternary and Nubian groundwater samples (61\% and 69\% respectively) are less than unity. This in turn may be attributed to the adsorption of sodium ions on the fine argillaceous sediments, (Starinsky et al., 1983). The rest of samples (39\% and 31\% respectively) in the same aquifers have values of $\mathrm{rNa}^{+} / \mathrm{rCl}^{-} \mathrm{more}$ than unity indicating fresh meteoric water recharge from the country rocks and also sodium may come from irrigation return flow and anthropogenic activity. According to Meybeck (1987) the release of $\mathrm{Na}^{+}$into groundwater may be due to the occurrence of cationic exchange or weathering of silicate minerals, typically albite as illustrated by the dissolution reaction below:

$$
2 \mathrm{NaAlSi}_{3} \mathrm{O}_{8} \text { (albite) }+9 \mathrm{H}_{2} \mathrm{O}+2 \mathrm{H}_{2} \mathrm{CO}_{3} \longrightarrow \mathrm{Al}_{2} \mathrm{Si}_{2} \mathrm{O}_{5}(\mathrm{OH})_{4}(\text { kaolinite })+2 \mathrm{Na}^{+}+2 \mathrm{HCO}_{3}^{-}+4 \mathrm{H}_{4} \mathrm{SiO}_{4}
$$

\section{2. $\left(\mathrm{rCa}^{2+} / \mathrm{rMg}^{2+}\right)$}

The $\mathrm{Ca}^{2+} / \mathrm{Mg}^{2+}$ ratio in $\mathrm{mmol} / \mathrm{l}$ of groundwater could reveal the dissolution of calcite and dolomite, $\mathrm{Ca}^{2+} / \mathrm{Mg}^{2+}=1$ indicating the dissolution of dolomite; the ratio $>2$ reflected an effect of silicate dissolution. The ratio between 1 and 2 indicated the dissolution of calcite (Maya and Loucks 1995). Figure 8 reveal that in the Quaternary and Nubian groundwater samples $\mathrm{Na}^{+} / \mathrm{Cl}^{-}>1$ or $<1$ and $\mathrm{Ca}^{2+} / \mathrm{Mg}^{2+}<1$ indicating dissolution of Halite and Calcite. Sample no 19 from the Quaternary samples has $\mathrm{Na}^{+} / \mathrm{Cl}^{-}>1$ and $\mathrm{Ca}^{2+} / \mathrm{Mg}^{2+}<1$ indicating Dolomite weathering, (Figure 8).

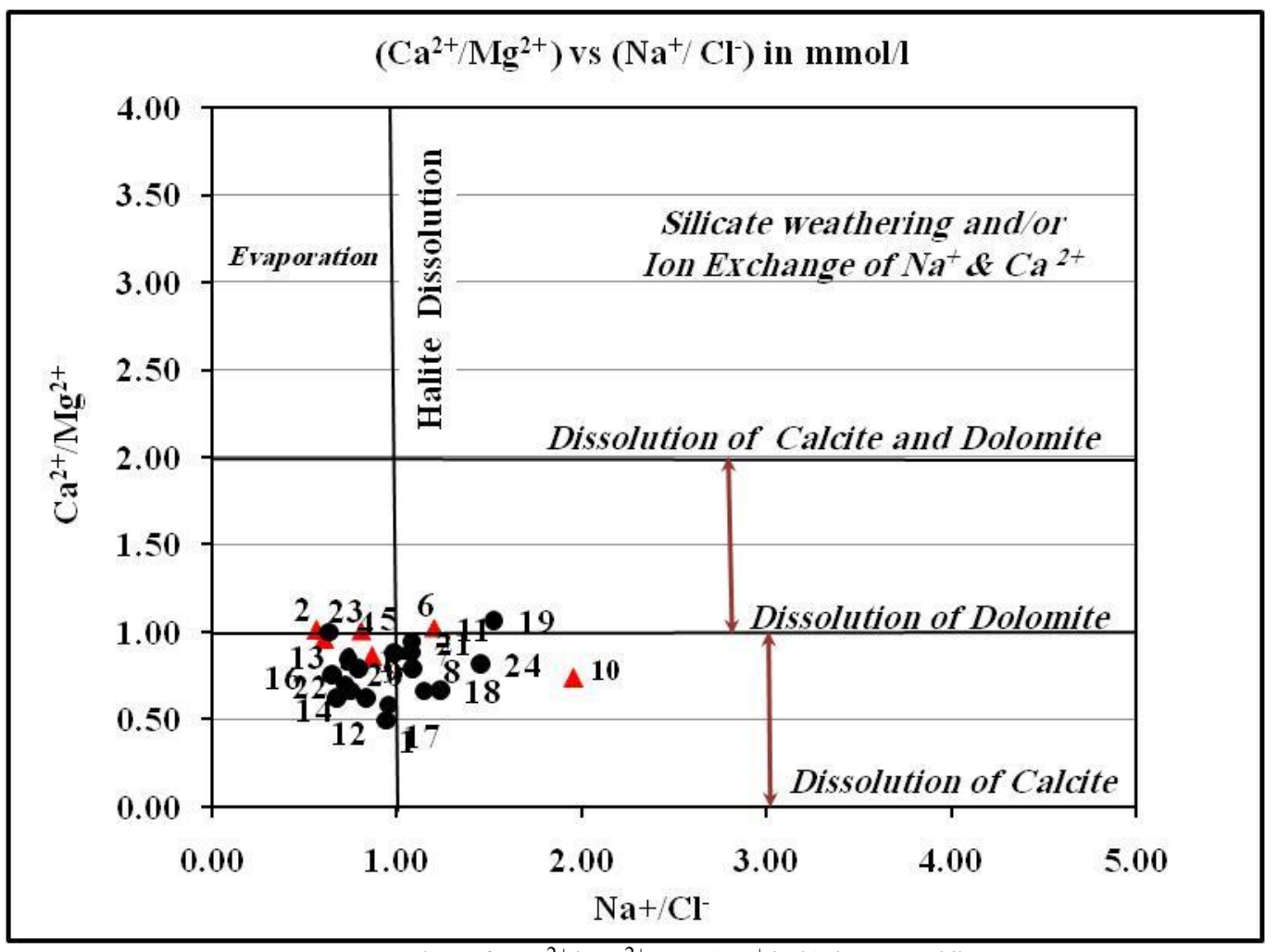

\section{3. $\left(\mathrm{rSO}_{4}{ }^{2-} / \mathrm{rCl}^{-}\right)$}

Fig. 8: Plot of $\left(\mathrm{Ca}^{2+} / \mathrm{Mg}^{2+}\right)$ vs $\left(\mathrm{Na}^{+} / \mathrm{Cl}^{-}\right)$in $\mathrm{mmol} / \mathrm{l}$

This ratio could be taken as a guide for detecting any excess of sulfate in groundwater (due to $\mathrm{CaSO}_{4}$ dissolution or $\mathrm{CaCO}_{3}$ precipitation) associated with sulfate mineral dissolution. The solubility of sulfate mineral components gradually increased in the hydrochemical composition by depth and distance from the recharge to the discharge area (Burdon, 1958). Consequently, the percolation of meteoric water and the greater distance of recharge area are the main factors of increasing the sulfate 
concentration by direct action of leaching processes. The $\left(\mathrm{SO}_{4}{ }^{2-} / \mathrm{Cl}^{-}\right)$ratio of all groundwater samples have values of $\mathrm{rSO}_{4}{ }^{2-} / \mathrm{rCl}^{-}$more than that in seawater $(0.1)$ in the two aquifers. This indicates the solution of the local terrestrial sulfate salts such as Gypsum, Anhydrite, Glauberite $\left(\mathrm{Na}_{2} \mathrm{SO}_{4} \cdot 10 \mathrm{H}_{2} \mathrm{O}\right)$ and Epsomite $\left(\mathrm{MgSO}_{4} \cdot 7 \mathrm{H}_{2} \mathrm{O}\right)$.

\section{4. $\left[\mathrm{rCl}^{-}-\mathbf{r}\left(\mathrm{Na}^{+}+\mathrm{K}^{+}\right)\right] / \mathrm{rCl}^{-}$(Ion-exchange index)}

This ratio has either negative or positive values. The negative values mean that alkaline earths $\left(\mathrm{Ca}^{2+}\right.$ and $\left.\mathrm{Mg}^{2+}\right)$ in water replace alkalis $\left(\mathrm{Na}^{+}+\mathrm{K}^{+}\right)$on the surface of clay minerals in the aquifer and vice versa in case of positive values. The majority of the Quaternary and Nubian groundwater samples (61\% and $67 \%$ respectively) have positive values of cation exchange index and vice versa in case of the rest groundwater samples (39\% and 33\% respectively) which have negative values of cation exchange index.

\section{Assemblages of hypothetical salts.}

According to Collin's (1923)the combination between major anions and cations reveals the formation of three groups (I, II and III) of hypothetical salts in the Quaternary groundwater samples and also three groups (I, II and IV) in the Nubian sandstone groundwater samples, (Table 5). From the results the majority $(95 \%)$ of the Quaternary groundwater samples are characterized by the assemblages II and III which have three sulfate salts (II, 39\%) as well as two chloride salts and two sulfate salts (III, 56\%), (More advanced stage)reflecting the meteoric water origin affected by leaching and dissolution of terrestrial salts.

Only one sample $(5 \%)$ of the Quaternary groundwater samples are characterized by assemblage I representing an earlier stage of chemical development (sample No. 17) than that of assemblage II and III. Also, assemblages I (two bicarbonate salts) reflect the dilution effect of River Nile and draining of Irrigation canal on the groundwater.

Concerning the Nubian sandstone groundwater, it is clear that, the majority of the groundwater samples $(67 \%)$ are characterized by the assemblages (II and IV) (more advanced stage, three sulfate salts (II) and three chloride salts (IV) which reflects the leaching and dissolution of terrestrial salts. The rest of samples are characterized by the assemblage I (33\%). Assemblages I represents an earlier stage of chemical development than that of assemblage II and IV. Assemblage I (two bicarbonate salts represent samples 10 and 11) reflects the effect of pure rain water on the groundwater.

Table 5: Assemblages of the hypothetical salts in the different aquifers

\begin{tabular}{llc}
\hline Aquifer & Assemblages of hypothetical salts in the study area & \% of water samples \\
\hline \multirow{3}{*}{ Quaternary } & $\mathrm{I}-\mathrm{NaCl}, \mathrm{Na}_{2} \mathrm{SO}_{4}, \mathrm{MgSO}_{4}, \mathrm{Mg}\left(\mathrm{HCO}_{3}\right)_{2}$ and $\mathrm{Ca}\left(\mathrm{HCO}_{3}\right)_{2}$ & 5 \\
& $\mathrm{II}-\mathrm{NaCl}, \mathrm{Na}_{2} \mathrm{SO}_{4}, \mathrm{MgSO}_{4}, \mathrm{CaSO} \mathrm{Ca}_{4}$ and $\mathrm{Ca}\left(\mathrm{HCO}_{3}\right)_{2}$ & 39 \\
& $\mathrm{III}-\mathrm{NaCl}, \mathrm{MgCl}_{2}, \mathrm{MgSO}_{4}, \mathrm{CaSO} \mathrm{Cand}_{4}$ and $\mathrm{Ca}\left(\mathrm{HCO}_{3}\right)_{2}$ & 56 \\
\hline \multirow{3}{*}{ Nubian sandstone } & $\mathrm{I}-\mathrm{NaCl}, \mathrm{Na}_{2} \mathrm{SO}_{4}, \mathrm{MgSO}_{4}, \mathrm{Mg}\left(\mathrm{HCO}_{3}\right)_{2}$ and Ca( $\left.\mathrm{HCO}_{3}\right)_{2}$ & 33 \\
& $\mathrm{II}-\mathrm{NaCl}_{2}, \mathrm{Na}_{2} \mathrm{SO}_{4}, \mathrm{MgSO}_{4}, \mathrm{CaSO}_{4}$ and $\mathrm{Ca}\left(\mathrm{HCO}_{3}\right)_{2}$ & 50 \\
& $\mathrm{IV}-\mathrm{NaCl}_{2} \mathrm{MgCl}_{2}, \mathrm{CaCl}_{2}, \mathrm{CaSO}_{4}$ and $\mathrm{Ca}\left(\mathrm{HCO}_{3}\right)_{2}$ & 17 \\
\hline
\end{tabular}

\section{Saturation indices}

Natural groundwater quality is influenced by mineral dissolution from aquifer-water interaction (Saleh et al., 1999) and is one of the main reasons of high TDS concentration, especially in arid regions. The extent to which the groundwater may be saturated with a given mineral species depends on the saturation index of that particular mineral species. If the groundwater is unsaturated with respect to a given mineral, it may continue to dissolve more of that mineral. Gradually, the groundwater may reach a stage where it is oversaturated with the mineral and that particular mineral species starts to precipitate (Deutsch 1997). The potential of a mineral to dissolve or precipitate in groundwater is determined by calculating the saturation index (SI) which is expressed as:

$$
\mathrm{SI}=\log \left(\mathrm{IAP} / K_{s p}\right)
$$

Where, IAP is the ion activity product and Ksp is the mineral solubility product. In the state of thermodynamic equilibrium, the SI of the mineral species is 0 . Mineral dissolution will occur in groundwater if that particular mineral species has a negative SI, whereas mineral precipitation will occur in groundwater if that particular mineral has a positive SI (Truesdell and Jones 1974). 
PHREEQC 2.8 speciation code was used to calculate SI of the analyzed groundwater samples. Figure (9) displays the saturation indices for the different mineral phases of the groundwater samples. The results show that groundwater in the two aquifers is undersaturated with respect to Gypsum and Anhydrite indicating the capacity of groundwater for more mineral dissolution. All samples of the Nubian sandstone and the most samples of the Quaternary groundwater are supersaturated with reference to Calcite, Aragonite and Dolomite.

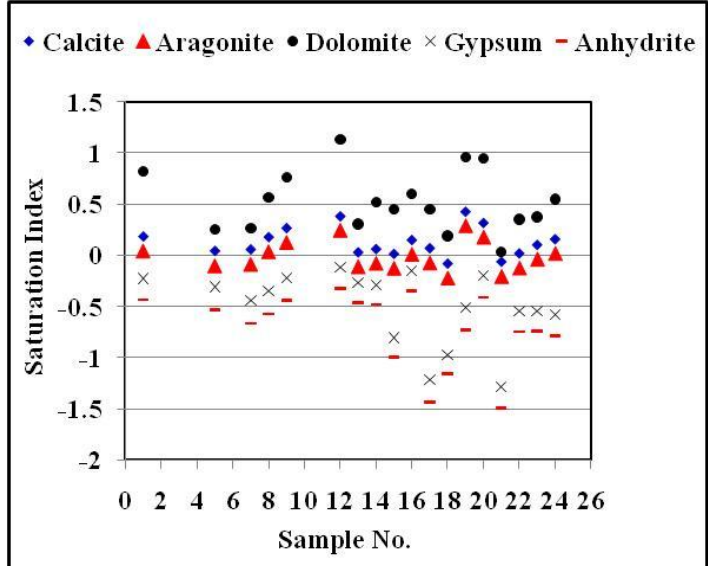

(a)

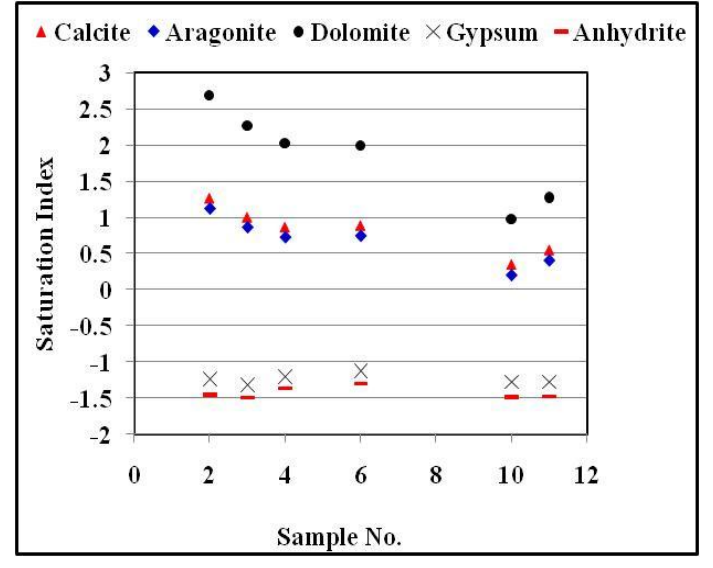

(b)

Fig. 9: Saturation indices of the principal mineral phases present in (a) the Quaternary groundwater and (b) the Nubian sandstone groundwater.

\section{Gibbs plot}

To ascertain the presence of rock-water interaction as shown by the saturation indices, Gibbs plot was also prepared. Gibbs (1970) demonstrated that the plot of $(\mathrm{Na}+\mathrm{K}) /(\mathrm{Na}+\mathrm{K}+\mathrm{Ca})$ versus TDS and $(\mathrm{Cl}) /\left(\mathrm{Cl}+\mathrm{HCO}_{3}\right)$ versus TDS shows the mechanism controlling groundwater chemistry. The different mechanisms include precipitation dominance, rock weathering dominance, and evaporation crystallization dominance. Groundwater influenced by evaporation/precipitation phenomenon typically shows TDS concentrations in excess of $1000 \mathrm{mg} / 1$. In the present study, all the groundwater samples in the two aquifers fall along the evaporation dominance (Figure10) indicating that the Evaporation/precipitation is the main mechanism and play a significant role in controlling the groundwater chemistry of the investigated area.

\section{Environmental stable isotopes of the groundwater in the study area:}

The groundwater stable isotopes (oxygen and hydrogen) of some selected wells from east Qift area are divided into two distinctive groups. Group (I) belonging to the deep flowing well in Laqita area and their isotopes ranged between -7.82 to $-5.8 \%$ for $\delta^{18} \mathrm{O}$ and between -58.20 to $-48.61 \%$ for $\delta \mathrm{D}$ (Table 6). The other group (II) of samples is enriched in their isotopic compositions and their isotopes are ranged between -1.4 to $1.0 \%$ for $\delta^{18} \mathrm{O}$ and between -14.8 to $-6.5 \%$ for $\delta \mathrm{D}$. Both groups are very different than the surface water (River Nile and irrigation canals) in Egypt where their average isotopic composition is 3.0 for $\delta^{18} \mathrm{O}$ and 34.0 for $\delta \mathrm{D}$, (Figure 11).

The stable isotopes compositions of the first group are apparently more depleted with respect to the modern meteoric precipitation (nowadays) and the shallow Quaternary aquifer. The isotopic composition of the groundwater of this group could be resulted from paleo-precipitation, which also would be mixed with modern precipitation. The relatively heavier isotopic compositions of the Quaternary wells in the other group of the study area reflect the residence time, the interaction between the surface water from the River Nile and the Irrigation canals, and also the evaporation from the water table. The relationship between $\delta^{18} \mathrm{O}$ and TDS can interpret the geochemical mechanism of groundwater caused by the evaporation on the basis that evaporation should increase the isotopic contents as well as chloride or TDS (Ezzeldin et al., 2018). If salinity has occurred because of the dissolution of evaporite salts by rainwater, groundwater would have the same content of $\delta^{18} \mathrm{O}$ or $\delta^{2} \mathrm{H} \%$ found in the original rainfall with high content of chloride or TDS. On the contrast, recharge 
from surface water should result in an increase in the heavy isotope content and low content of chloride. The relationship between $\delta{ }^{18} \mathrm{O}$ and TDS (Figure 12) reflects two main water types. The first type is water, which is mainly influenced by evaporation and to some extent affected by leaching and dissolution of terrestrial salts that lead to salinization. The second type is water that diluted by the return irrigation water and surface water (Mohammed, 2016).
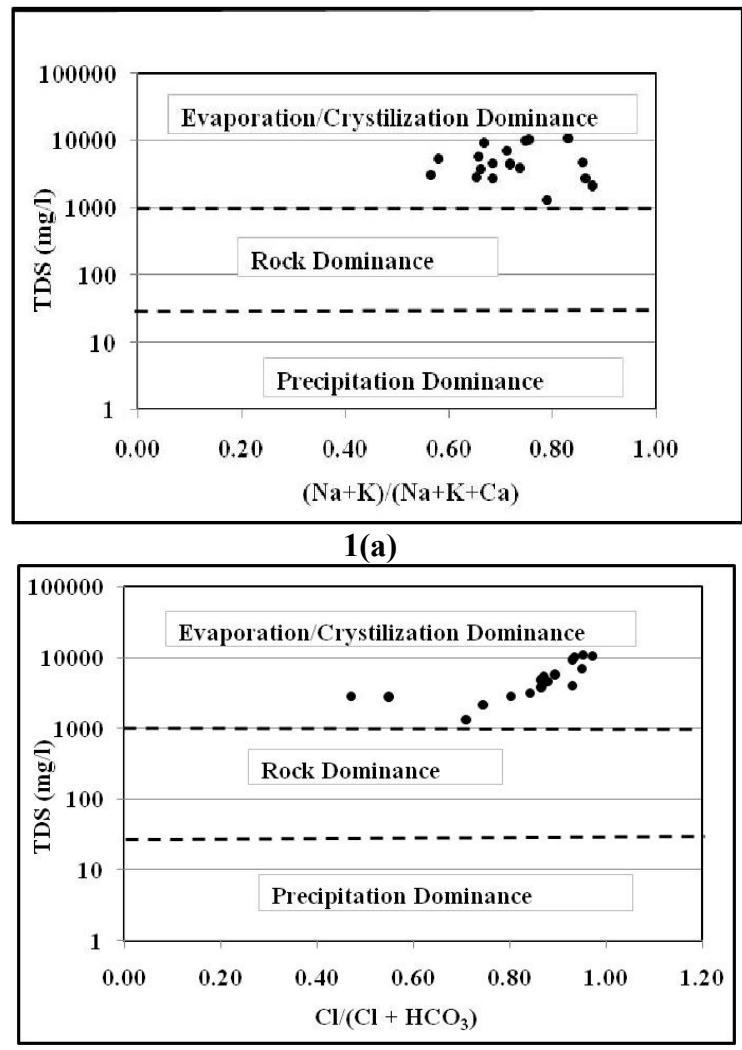

1(b)

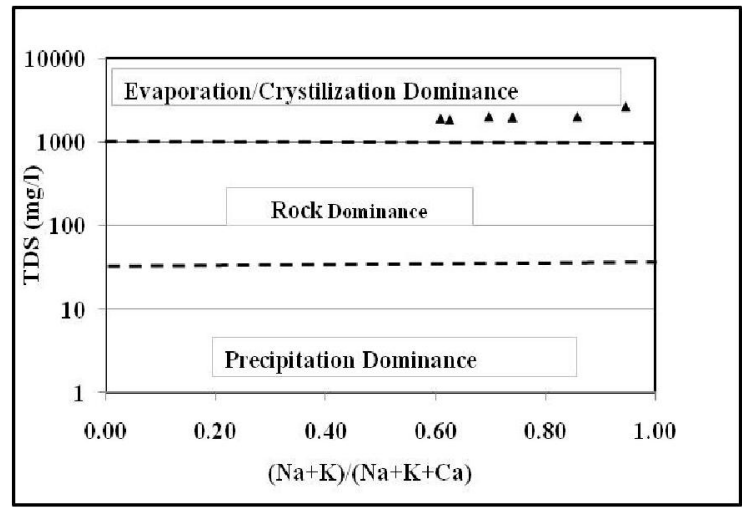

2(a)

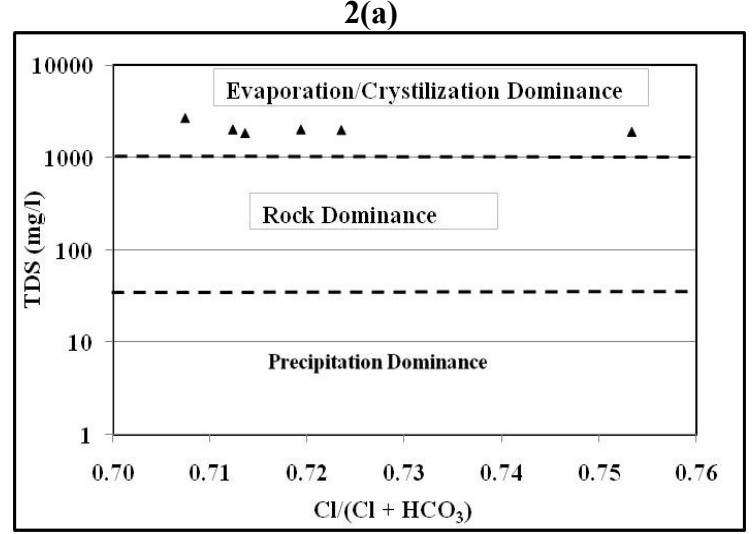

2(b)

Fig. 10: Gibbs diagram showing the mechanism controlling the ionic concentrations in the Quaternary groundwater aquifer (1) and Nubian sandstone aquifer (2): a TDS versus $(\mathrm{Na}+\mathrm{K}) /\left(\mathrm{Na}+\mathrm{K}+\mathrm{Ca}_{2}\right)$ and $\mathrm{b}$ TDS versus $\mathrm{Cl} /\left(\mathrm{Cl}+\mathrm{HCO}_{3}\right)$.

Table 6: Isotopic data of groundwater and surface water collected from the study area (2019).

\begin{tabular}{|c|c|c|c|c|c|}
\hline Sample No. & $\begin{array}{l}\delta^{18} O \\
\% \text { o } \\
\end{array}$ & $\begin{array}{l}\delta^{2} H \\
\% 0 \\
\end{array}$ & & $\begin{array}{l}\text { Location } \\
\text { Lat }\end{array}$ & Long \\
\hline Quaternary aquifer & & & \multirow{5}{*}{ Group II } & & \\
\hline 15 & 1 & -6.5 & & 32.89581 & 25.98394 \\
\hline 16 & -0.2 & -6.9 & & 32.88557 & 25.02397 \\
\hline 17 & -0.9 & -13.7 & & 32.8849 & 26.05511 \\
\hline 18 & -1.4 & -14.8 & & 32.87798 & 26.05637 \\
\hline River Nile, $\mathbf{S 1}$ & 3.0 & 34.1 & & & \\
\hline Irrigation canal, S2 & 3.2 & 34 & & & \\
\hline \multicolumn{6}{|c|}{ Nubian Sandstone aquifer } \\
\hline 2 & -7.82 & -58.2 & \multirow{4}{*}{ Group I } & 33.14549 & 25.89056 \\
\hline 3 & -5.62 & -49.52 & & 33.14198 & 25.8948 \\
\hline 4 & -7.0 & -55.53 & & 33.13613 & 25.89317 \\
\hline 6 & -7.88 & -50.45 & & 33.13031 & 25.88561 \\
\hline
\end{tabular}




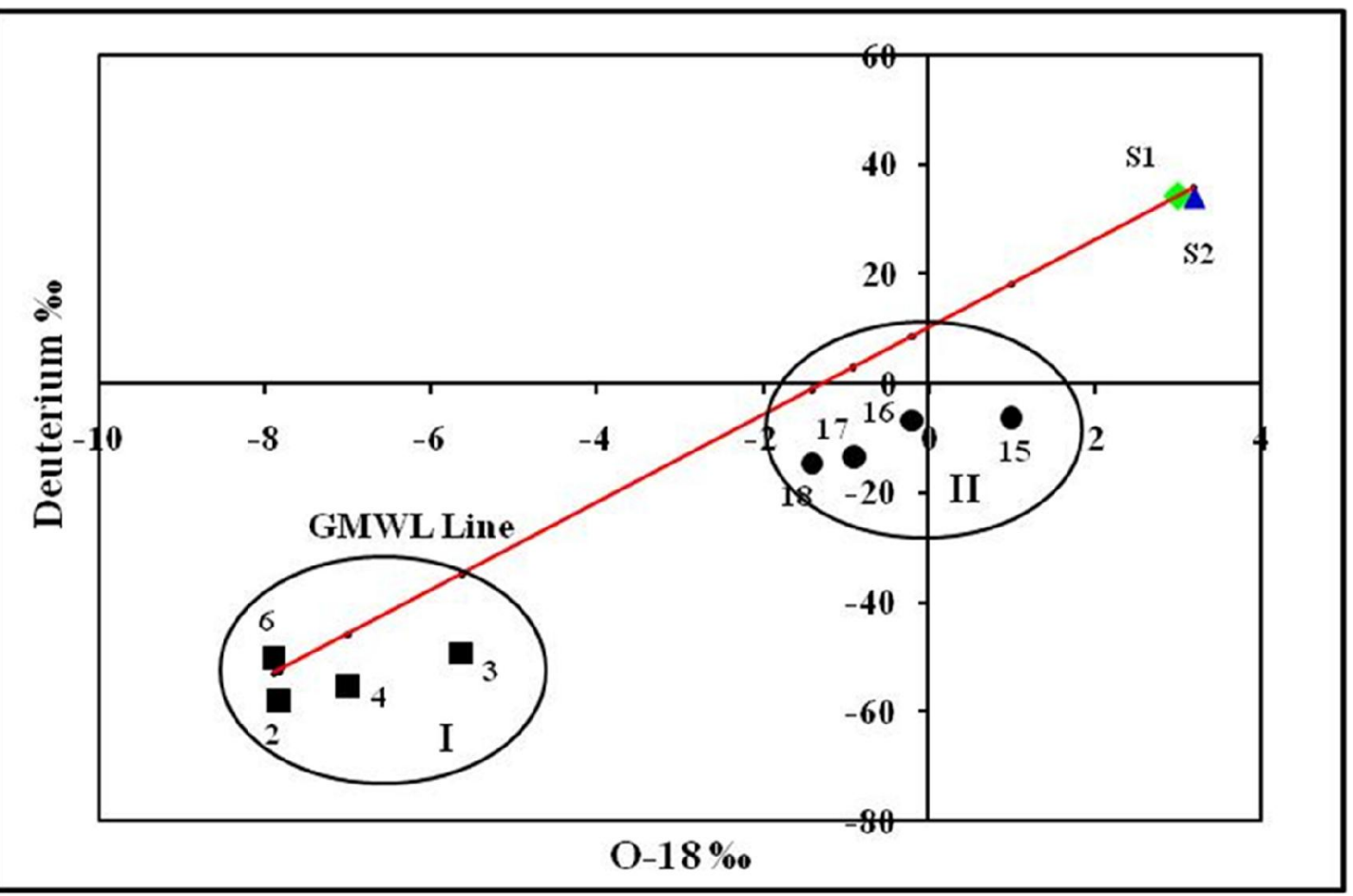

Fig. 11: Stable isotopic compositions $\left(\delta^{18} \mathrm{Oand} \delta^{2} \mathrm{H}\right)$ of samples included in the study area.

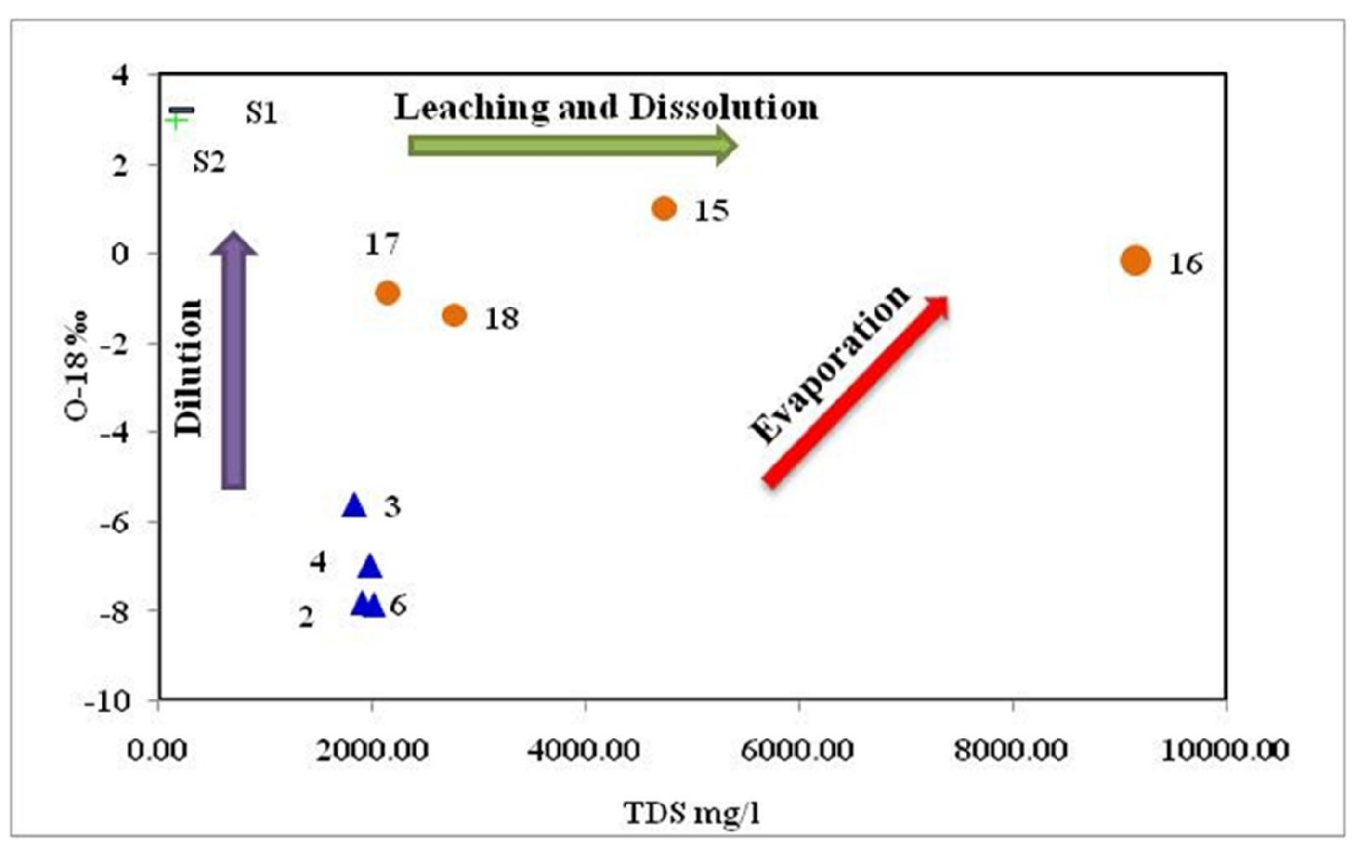

Fig. 12: Salinity- $\delta 180$ diagram of the studied groundwater and surface water samples

\section{Evaluation of groundwater for different purposes}

\subsection{Municipal purpose}

The suitability of the Quaternary groundwater and Nubian groundwater for drinking purposes were evaluated based on the Egyptian drinking water quality standards (ARE 2007). A comparison between the allowable limits for the TDS, cations and anions is given in Table 7. According to the table, all the groundwater are not suitable for drinking purposes, as all the samples contain concentration of one element or other above the allowable limits for drinking purposes. 
Table 7: Water quality assessment for drinking purposes in the Quaternary and Nubian sandstone aquifers

\begin{tabular}{|c|c|c|c|c|c|c|c|}
\hline Element & pH & $\mathbf{C a}$ & Mg & $\mathbf{N a}$ & $\mathrm{SO}_{4}$ & Cl & TDS \\
\hline $\begin{array}{l}\text { Allowable limit } \\
\text { (ppm) } \\
\text { According to } \\
\text { (ARE, 2007) }\end{array}$ & $6.5-8.5$ & 350 & 150 & 200 & 250 & 250 & 1000 \\
\hline \multicolumn{8}{|c|}{ Quaternary aquifer } \\
\hline Suitable & All samples & $\begin{array}{c}7,8,15,17 \\
18,19,21 \\
22 \& 24\end{array}$ & $\begin{array}{c}17,18,19 \& \\
21\end{array}$ & non & non & non & non \\
\hline$\%$ & 100 & 50 & 22 & 0 & 0 & 0 & 0 \\
\hline Unsuitable & non & $\begin{array}{c}1,5,9,12 \\
13,14,16 \\
20 \& 23\end{array}$ & $\begin{array}{c}1,5,7,8,9 \\
12,13,14 \\
15,16,20 \\
22,23 \& 24 \\
\end{array}$ & $\begin{array}{c}\text { All } \\
\text { samples }\end{array}$ & $\begin{array}{c}\text { All } \\
\text { samples }\end{array}$ & $\begin{array}{c}\text { All } \\
\text { samples }\end{array}$ & $\begin{array}{c}\text { All } \\
\text { samples }\end{array}$ \\
\hline$\%$ & 0 & 50 & 78 & 100 & 100 & 100 & 100 \\
\hline $\begin{array}{l}\text { Nubian aquifer } \\
\text { Suitable }\end{array}$ & All samples & All samples & All samples & non & $2 \& 3$ & non & non \\
\hline$\%$ & 100 & 100 & 100 & 0 & 33 & 0 & 0 \\
\hline Unsuitable & non & non & non & $\begin{array}{c}\text { All } \\
\text { samples }\end{array}$ & $\begin{array}{c}4,6,10 \\
\& 11 \\
\end{array}$ & $\begin{array}{c}\text { All } \\
\text { samples }\end{array}$ & $\begin{array}{c}\text { All } \\
\text { samples }\end{array}$ \\
\hline$\%$ & 0 & 0 & 0 & 100 & 67 & 100 & 100 \\
\hline
\end{tabular}

\subsection{Evaluation of groundwater quality for drinking of livestock and poultry}

Water to be used by livestock is generally subjected to quality limitations like those of humans. However, livestock is generally able to consume waters of high mineral content than recommended for human consumption. The classification of Mckee and Wolf, 1963 was used in the present study. Accordingly, the studied groundwater can be evaluated as the follows; For the Quaternary groundwater samples; about $28 \%$ of Quaternary groundwater samples having salinities in the range of $1000-3000 \mathrm{mg} / 1$, so they are considered very satisfactory for all classes of livestock and poultry. Also $33 \%$ of Quaternary groundwater samples have salinities in the range of 3000-5000, hence they are considered satisfactory for livestock but poor with some risks for poultry. $17 \%$ of the Quaternary groundwater samples have salinity range of 5000-7000, so they can be used with reasonable safety for dairy and beef cattle, sheep, swine, and horses. Avoid use for pregnant or lactating animals should be considered and non acceptable for poultry is also recognized. About $11 \%$ of the Quaternary groundwater samples have salinities in the range $7000-10000 \mathrm{mg} / \mathrm{l}$, these samples are unfit for poultry and probably for swine. Considerable risk is expected in using for pregnant or lactating cows, horses or sheep, or for the young of these species. The rest of the Quaternary groundwater samples $(11 \%)$ have salinities more than $10000 \mathrm{mg} / \mathrm{l}$, so they are risky with these highly saline waters are so great they cannot be recommended for use under any condition. On the other hand, all the groundwater samples of the Nubian sandstone aquifer are considered very satisfactory for all classes of livestock and poultry where it has salinities in the range of $1000-3000 \mathrm{mg} / \mathrm{l}$.

\subsection{Irrigation purposes}

$\mathrm{Na}$ or alkali-hazard expressed in terms of sodium adsorption ratio (SAR) iswidely used. If waters used for irrigation are high in $\mathrm{Na}^{+}$and low in $\mathrm{Ca}^{2+}$, the ion-exchange sites may become saturated with $\mathrm{Na}^{+}$, which destroys the soil structure, because of dispersion of the clay particles. Such soils reduce plant growth. The SAR for the studied waters is computed, using the formula (Hem, 1992):

$$
\mathrm{SAR}=\mathrm{Na}^{+} /\left(\left(\mathrm{Ca}^{2++} \mathrm{Mg}^{2++}\right) / 2\right)^{0.5}
$$

Where, the ion concentrations are expressed in meq/l. The computed SAR values for water samples in the Quaternary groundwater samples range from 4.67 to 17.3, with an average value of 9.36 and in the Nubian groundwater samples the values range from 4.22 to 21.5 with an average value of 8.9. The SAR versus EC plot (Figure 13) shows that about $11 \%$ of the Quaternary groundwater samples are moderate water quality for irrigation. Only $5 \%$ of the Quaternary groundwater samples are 
Intermediate quality for irrigation and $5 \%$ of the same aquifer samples are bad water class, the rest of samples (79\%) of the Quaternary groundwater samples are out of range. In addition the majority of the Nubian sandstone groundwater samples (67\%) are moderate water quality for irrigation and $17 \%$ of the groundwater samples in the same aquifer are Intermediate quality for irrigation while $17 \%$ are bad water quality.

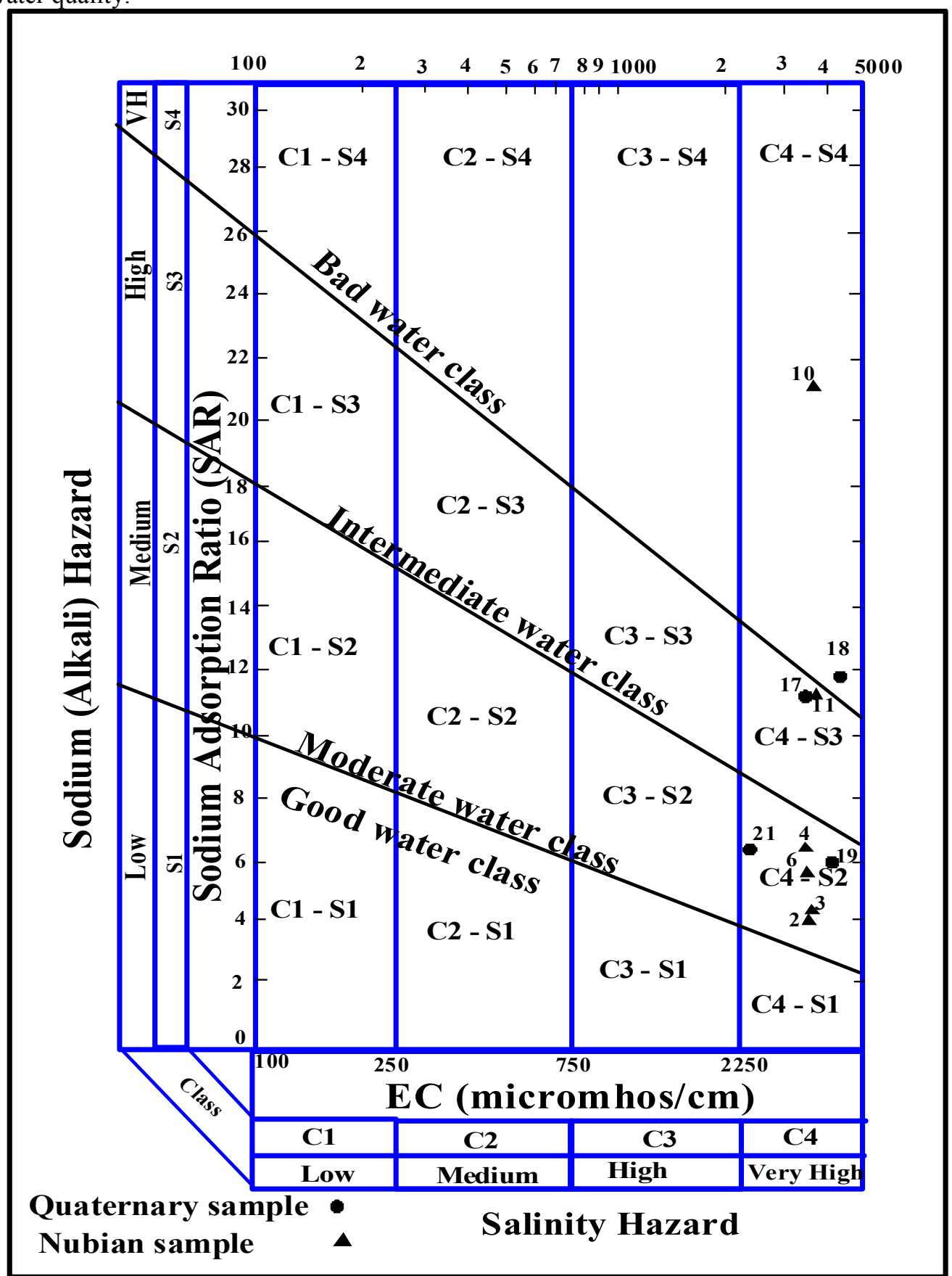

Fig. 13: Natural water quality for irrigation purposes in the study area, after Richard 1954.

\section{Conclusion}

Hydrogeochemical study for sustainable development in Wadi El-Mathula is depending on the data of 24 wells; 18 wells of the total wells are tapping the Quaternary aquifer, 6 wells are tapping Nubian sandstone aquifer and two surface water samples. The groundwater in the Quaternary aquifer belongs to fresh, brackish and saline categories. While all the groundwater samples of the Nubian 
sandstone aquifer are brackish water. Calcite and Dolomite dissolution beside the dissolution of Halite are the main hydrochemical processes affecting groundwater quality. The results indicated that the groundwater in the two aquifers is undersaturated with respect to Gypsum and Anhydrite and all samples of the Nubian sandstone and the most samples of the Quaternary groundwater are supersaturated with Calcite, Aragonite and Dolomite. The results of the environmental stable isotopes indicated that the groundwater in study area is discriminated into two distinctive groups. Group (I) in Laqita area (Nubian aquifer) and group (II) of samples is enriched in their isotopic compositions (Quaternary aquifer). The groundwater in the two aquifers is not suitable for drinking purposes. Only $28 \%$ of the Quaternary groundwater samples are considered very satisfactory for all classes of livestock and poultry. On the other hand, all groundwater samples of the Nubian sandstone aquifer are considered very satisfactory for all classes of livestock and poultry. A few of the Quaternary groundwater samples are intermediate quality for irrigation, while the majority of the Nubian sandstone groundwater samples are moderate water quality for irrigation.

\section{References}

Abdalla, F., 1995. Geoelectrical studies at WadiZeiduen Eastern Desert, Egypt. M.Sc. Thesis. Faculty of Science, South Valley University, Qena, Egypt.

Abd-Allatief, T.A., A.A. Abd El-Rahman, S.H. Sabet, A.M. Saad, and M.Z.T. Ali, 2012. Delineating the ground water occurrence using geophysical methods inWadi El-Mathula area, Qena, Egypt. Assiut University, Journal of Geeology.

Abdel Razik, T.M. and A.V. Razvaliaev, 1972. On the Tectonic Origin of the Nile Valley Between Idfu and Qena, Egypt, Egyptian Journal of Geology, 16(2).

Abdel Moneim A., 2004. Overview of the geomorphological and hydrogeological characteristics of the Eastern Desert of Egypt. Hydrogeol. J 13:416-425.

Abu Al-Izz, M. S., 1971. Land forms of Egypt. The American University Press, Cairo

Abu El-Ela, S., H. Ibrahim, and A. El-Hussaini, 1997. Geoelectrical and hydrogeological studies on the sediments of the main trunk, Wadi El-Mathula Basin, Eastern Desert, International Desalination Association, Madrid, Spain. PP. 99-115.

American Society for Testing and Materials, (ASTM), 2002. Water and environmental technology. Annual book of ASTM standards.

Amer, K. M., 1970. Petrography and Stratigraphy of the Cretaceous in the Eastern Desert, Egypt, and Their Evaluation for Economic Mineral Deposits, M.Sc. Fac. Of Sc. Ain Shams Univ., A.R.E.

ARE, Drinking Water Standard, 2007. Guideline for drinking water quality standards. Ministry of Housing, Egypt.

Burdon, D. J., 1958. Metasomatism of groundwater at depth.UNESCO course on hydrogeology, Desert Institute, Cairo, Egypt.

Collin, A. G., 1923. Geochemistry of oil field waters.” Elsevier, Sci. Publ. Comp., Amesterdam, The Netherlands. 475.

Craig, H., 1961. Isotopic variations in meteoric waters. Science 133: 1702-1703

Deutsch, W. J., 1997. Groundwater geochemistry: fundamentals and applications to contamination. Lewis, New York.

Egyptian Geological Survey and Mining Authority, (EGSMA), 1987. Geologic Map of the Aswan Quadrangle, Scale 1:500000, Egypt, 1978.

El-Fakharany, M.A., and K.A. Dahab, 1997. Hydrogeological Studies on Wadi Al-Qarn Basin, Eastern Desert, Egypt, Scient J, Fac. Sci., Menofia University, v. 11.

El-Fakharany, N.A., 1998. Drainage basins and flash floods managements in the area southeast Qena, Eastern Desert, Egypt. Egptian Journal of Geology 42(2):737-750.

El-Ghawaby, M.A., 1973. Structural Geology and Radioactive Mineralization of WadiZeidun area, Eastern Desert, Ph. D. Thesis, Ain Shams University, Egypt.

El-Hussaini, A. H., A.R. El younsy, and M.M. Senosy, 1990. Geological and Geoelectrical Studies on the Entrance of Wadi El-Mathula, Eastern Desert, Egypt, Bull. Fac. Sci., Assiut University.

El-Rakaiby, M., 1990. Tectonic lineaments of the basement belt of Eastern Desert. Egypt J Geol 32:77-95. 
El-Shamy, I.Z., 1985. Quantitative Geomorphology and Surface Water Conservation in WadiMatulaWadiAbbad Area, Central Eastern Desert, Annals of the Geological Survey of Egypt, vol. xv.

El Tahlawi M. R., A.A. Farrag, and S.S. Ahmed, 2008. Groundwater of Egypt: an environmental overview. Environ Geol 55:639-652.

Ezzeldin, H.A., A. Kamal, A.M. Reda, K. Guindy, and I.Z. El-Shamy, 2018. Assessment of Factors Affecting the Groundwater Quality in El-Hammam Area, North-West Coast of Egypt. Middle East Journal of Applied Sciences, V (8) p 798-819.

Farrage, A.A., H.A. Ibrahim, and M.M. Attia, 1996. Evaluation of the soil and groundwater resources in WadiAttwani and Qusur El-Banat areas, Qift-Quseir road, Eastern Desert, Egypt. In: 1st International Conference on Basic Sciences and Advanced Technology, Assuit, Egypt.

Fishman, M. J. and L.C. Friedman, 1985. Methods for determination of inorganic substances in water and fluvial sediments. U.S. Geol. Surv. Book 5, Chapter A1.Open File Report 85-495, Denver, Colorado, U.S.A (84).

Freeze, R. A. and J.A. Cherry, 1979. Groundwater. Prentice Hall, Inc., Englewood Cliffs, New Jersey, U.S.A.

Geriesh, M. H., 1998. Hydrogeological Assessment of the Groundwater Resources Around the Nile Valley Between Qift and Nag-Hammadi, Upper Egypt, Al-Azhar bull. Sci., vol. 9 no. 1.

Ghanem, M., A.A. Zalata, T.M. Abdel Razik, S. Said, L. Mikhalilov, A.V. Razvaliaev, and Y. Mirov, 1970. Stratigraphy of the Phosphate-Bearing Cretaceous and Paleogene Sediments of the Nile Valley Between Idfu and Qena; in O. Moharram et al., "Studies on Some Minerals Deposits of Egypt", Egyptian Geological Survey, Cairo.

Gibbs, R.J., 1970. Mechanisms controlling world water chemistry. Science, 170(3962):1088-1090

Hem, J.D., 1992. Study and interpretation of the chemical characteristics of natural water. U.S. Geological Survey Water -Supply Paper 2254, 263 P.

Ibrahim H.A., S. Abu El-Ella, and M. Attia, 1997. Application of shallow seismic refraction techniques to hydrologic investigations on the main trunk of Wadi El-Mutula, Eastern Desert, Egypt. International Desalination Association, Madrid, pp 479-493.

Issawi, B., A.M. Abdallah, and M. Said, 1987. Geology of Wadi El Mashash Area, Eastern Desert, Annals Geol. Survey, vol. VII.

Maya A. L. and M.D. Loucks, 1995. Solute and isotopic geochemistry and groundwater flow in the Central Wasatch Range. Utah. J. Hydrol. Vol. 172, pp. 31-59.

Mckee, J. E., and H.W. Wolf, 1963. water quality criteria. California State Water Quality Board, Publ., 3A., U.S.A.

Meyback, M., 1987. Global chemical weathering of surficial rocks estimated from river dissolved loads. American Journal of Science, 287, 401-428.

Mohammed, A., R.V. Krishnamurthy, E.K. Alan, L.J. Crossey, and K.K. Karl, 2016. Factors affecting the stable isotopes ratios in groundwater impacted by intense agricultural practices: A case study from the Nile Valley of Egypt, Science of the Total Environment (573): 707-715.

Piper, A.M., 1944. A graphic procedure in the geochemical interpretation of water analyses. Trans. Amer. Geophys. Union, 25, PP 914-923.

Rainwater, F. H. and L.L. Thatcher, 1960. Methods for collection and analysis of water samples. U. S. Geol. Survey water supply, 301P.

Regwa, 1983. Special Studies on the Groundwater Aquifers in El-Laquita Area, Internal Report.

Richard L.A., 1954. Diagnosis and Improvement of Saline and Alkali Soils.US Department of Agriculture Hand Book, 60.

Sabet, A. H., V.B. Tsogoev, A.A. Zalat, and E.M. Bagadaev, 1985. Geologic Map, El-Laquita Sheet, Eastern Desert, the Egyptian Authority for Geological Survey and Mining.

Said, R., 1962. The geology of Egypt: Elsevier Pub. Co., Amesterdam, New York.

Said, R., 1981. The geological Evolution of River Nile, Spring-Verlag, New York.Inc.

Saleh, A., F. Al-Ruwaih, and M. Shehat, 1999. Hydrogeochemical processes operating within the main aquifers of Kuwait. J Arid Environ 42:195-209.

Senosy, M.M., 1988. Geological and geoelectrical studies on the entrance of Wadi El Mathula area, Eastern Desert, Egypt. M. Sc. Thesis, Geol. Dept., Fac. Sci., Assiut Univ., Egypt. 
Soliman, M.A., M.E. Habib, and E.A. Ahmed, 1986. Sedimentologic and Tectonic Evolution of the Upper Cretaceous-Lower Tertiary Succession at WadiQena, Egypt, Sedimentary Geology, 46, PP 111-133, El-Sevier Sci. Pub. B.V., Amsterdam.

Starinsky, A., M. Bielski, A. Ecker, and G. Steinitz, 1983. Tracing the origin of salts in groundwater by $\mathrm{Sr}$ isotopic composition (The crystalline complex of the southern Sinai), Egypt". Isotope Geoscience, 1:257-267.

Truesdell, A.H, and B.F. Jones, 1974. WATEQ, a computer program for calculating chemical equilibria of natural waters. J. Res. US Geol. Surv, 2(2):233-248.

Tawfik, M.Z., 2011. Geophysical Exploration for Groundwater Occurrence in Wadi El-Mathula Basin, Qena, Egypt. Ph.D. Thesis, Fac. Sci. Assiut Univ., Assiut, Egypt. 130.

Youssef, M.I., 1957. Upper Cretaceous Rocks in Qusseir Area, Bull. Inst. Desert, 7(2):35-54. 